\title{
Nucleus Accumbens AMPA Receptors Are Necessary for Morphine-Withdrawal-Induced Negative-Affective States in Rats
}

\author{
Shayla E. Russell, Daniel J. Puttick, Allison M. Sawyer, David N. Potter, Stephen Mague, William A. Carlezon Jr, \\ and Elena H. Chartoff \\ Department of Psychiatry, Harvard Medical School, McLean Hospital, Belmont, Massachusetts 02478
}

\begin{abstract}
Dependence is a hallmark feature of opiate addiction and is defined by the emergence of somatic and affective withdrawal signs. The nucleus accumbens (NAc) integrates dopaminergic and glutamatergic inputs to mediate rewarding and aversive properties of opiates. Evidence suggests that AMPA glutamate-receptor-dependent synaptic plasticity within the NAc underlies aspects of addiction. However, the degree to which NAc AMPA receptors (AMPARs) contribute to somatic and affective signs of opiate withdrawal is not fully understood. Here, we show that microinjection of the AMPAR antagonist NBQX into the NAc shell of morphine-dependent rats prevented naloxone-induced conditioned place aversions and decreases in sensitivity to brain stimulation reward, but had no effect on somatic withdrawal signs. Using a protein cross-linking approach, we found that the surface/intracellular ratio of NAc GluA1, but not GluA2, increased with morphine treatment, suggesting postsynaptic insertion of GluA2-lacking AMPARs. Consistent with this, 1-naphthylacetyl spermine trihydrochloride (NASPM), an antagonist of GluA2-lacking AMPARs, attenuated naloxone-induced decreases in sensitivity to brain stimulation reward. Naloxone decreased the surface/intracellular ratio and synaptosomal membrane levels of NAc GluA1 in morphine-dependent rats, suggesting a compensatory removal of AMPARs from synaptic zones. Together, these findings indicate that chronic morphine increases synaptic availability of GluA1-containing AMPARs in the NAc, which is necessary for triggering negativeaffective states in response to naloxone. This is broadly consistent with the hypothesis that activation of NAc neurons produces acute aversive states and raises the possibility that inhibiting AMPA transmission selectively in the NAc may have therapeutic value in the treatment of addiction.
\end{abstract}

Key words: GluA1; glutamate; ICSS; opiate; place conditioning; withdrawal

Significance Statement

Morphine dependence and withdrawal result in profound negative-affective states that play a major role in the maintenance of addiction. However, the underlying neurobiological mechanisms are not fully understood. We use a rat model of morphine dependence to show that GluA1 subunits of AMPA glutamate receptors in the nucleus accumbens (NAc), a brain region critical for modulating affective states, are necessary for aversive effects of morphine withdrawal. Using biochemical methods in NAc tissue, we show that morphine dependence increases cell surface expression of GluA1, suggesting that neurons in this area are primed for increased AMPA receptor activation upon withdrawal. This work is important because it suggests that targeting AMPA receptor trafficking and activation could provide novel targets for addiction treatment.

\section{Introduction}

Opiates such as morphine are initially abused because of their euphoric effects (Wise, 1989), which facilitates continued drug

\footnotetext{
Received June 14, 2012; revised April 11, 2016; accepted April 17, 2016.

Author contributions: W.A.C. and E.H.C. designed research; S.E.R., D.J.P., A.M.S., D.N.P., S.M., and E.H.C. performed research; S.E.R., D.J.P., A.M.S., D.N.P., S.M., and E.H.C. analyzed data; E.H.C. wrote the paper

This work was supported by the National Institutes of Health (National Institute on Drug Abuse, NIDA, Grant DA023606 to E.H.C.).

The authors declare no competing financial interests.

Correspondence should be addressed to Elena Chartoff, McLean Hospital, 115 Mill Street, Belmont, MA 02478.

E-mail: echartoff@mclean.harvard.edu.
}

taking such that tolerance to the hedonic effects of the drug and dependence eventually develop (Koob and Le Moal, 2001). Highly aversive physical and psychological withdrawal symptoms characterize opiate dependence (Koob et al., 1989; Nestler, 1996), which can increase craving and the risk of relapse. Alleviation of withdrawal-induced negative-affective states becomes a primary motivation for continued drug use (Wikler, 1948; Hasin et al., 2002; Baker et al., 2004; Cottone et al., 2009). Unfortu-

DOI:10.1523/JNEUROSCI.2875-12.2016

Copyright $\odot 2016$ the authors $\quad 0270-6474 / 16 / 365748-15 \$ 15.00 / 0$ 
nately, the neurobiological mechanisms underlying druginduced negative-affective states are not well understood.

Animal models of morphine dependence have revealed the importance of the nucleus accumbens (NAc) - a critical substrate for reward that integrates dopaminergic and glutamatergic inputs (Carlezon and Thomas, 2009)—in mediating morphine reward, as well as negative-affective states and some somatic signs associated with morphine withdrawal (Olds, 1982; Koob et al., 1992; Harris and Aston-Jones, 1994; Zhu et al., 2016). Increasing evidence suggests that glutamate-dependent presynaptic and postsynaptic plasticity within the NAc underlies aspects of drug dependence (Carlezon and Nestler, 2002; Wolf et al., 2004; Kalivas, 2009). Acute morphine decreases extracellular levels of glutamate in the NAc, and this effect shows tolerance after repeated morphine use (Sepúlveda et al., 1998). After chronic morphine use, precipitated or spontaneous withdrawal results in a prolonged increase in glutamate levels in the NAc (Sepúlveda et al., 1998; Sepúlveda et al., 2004), similar to observations in the locus ceruleus of morphine-dependent rats (Hong et al., 1993). Recently, it has been shown that abstinence from repeated morphine treatment results in an increase in glutamate release probability specifically at dopamine D1 receptor-expressing neurons in the NAc (Hearing et al., 2016). The mechanisms underlying altered glutamate transmission are not known, but may involve neuroadaptations in synaptic release and clearance of extracellular glutamate (Nakagawa et al., 2001; Sekiya et al., 2004; Kalivas, 2009).

There is also increasing evidence for drug-induced postsynaptic alterations in AMPAR-mediated glutamate transmission. In the context of the current study, it has been shown recently that chronic morphine increased insertion of AMPA GluA2-lacking receptors in the NAc and potentiated AMPAR-mediated transmission (Zhu et al., 2016). Likewise, systemic administration of an AMPAR antagonist to rats or genetic deletion of the GluA1 AMPAR subunit in mice decreases somatic signs of morphine withdrawal (Rasmussen et al., 1996; Vekovischeva et al., 2001). Here, we tested the hypothesis that activation of AMPARs in the NAc is necessary for morphinewithdrawal-induced negative-affective states. Rats were made morphine dependent via subcutaneous implantation of morphine pellets and the effects of intra-NAc shell microinjections of the AMPAR antagonist NBQX on naloxone-induced conditioned place aversions, decreases in brain stimulation reward, and somatic withdrawal signs were measured. To determine whether chronic morphine affects postsynaptic AMPAR levels or function in the NAc, separate rats were used to measure the effects of morphine dependence and naloxone-precipitated withdrawal on subcellular localization of AMPAR subunits GluA1 and GluA2. We focused on the NAc shell because previous work has demonstrated that this region plays a critical role in drug reward and aversion (Carlezon and Wise, 1996; Bari and Pierce, 2005; Chartoff et al., 2006a), because affective signs of morphine withdrawal are associated with activation of c-fos in the NAc shell but not the core (Gracy et al., 2001), and because there is a higher prevalence of mu-opioid receptors in the shell compared with the core (Svingos et al., 1997).

\section{Materials and Methods}

Rats and surgery. A total of 235 male Sprague Dawley rats (Charles River Laboratories) were used in this study. Rats weighed 325-375 g at the time of the experiments and were housed individually after surgery on a $12 \mathrm{~h}$ light/dark (7:00 A.M. to 7:00 P.M.) cycle with ad libitum access to food and water except during testing. All experiments were conducted during the light phase. For all intracranial stereotactic surgeries, rats were anesthetized with intraperitoneal pentobarbital ( $65 \mathrm{mg} / \mathrm{kg}$, IP) supplemented with subcutaneous atropine $(0.25 \mathrm{mg} / \mathrm{kg}, \mathrm{SC})$ to minimize bronchial secretions. For experiments involving only implantation of intracranial cannulae aimed at the NAc shell, 118 rats were used. Bilateral guide cannulae (26-gauge; Plastics One) were aimed $1 \mathrm{~mm}$ above the ventral NAc shell ( $1.5 \mathrm{~mm}$ anterior to bregma, $\pm 1.0 \mathrm{~mm}$ lateral from midline, and $5.9 \mathrm{~mm}$ ventral to dura; Paxinos, 1995), as described previously (Chartoff et al., 2009). This area corresponds to the intermediate zone of the NAc shell (Todtenkopf and Stellar, 2000). For experiments involving implantation of cannulae aimed at the NAc shell and intracranial selfstimulation (ICSS) electrodes, 33 rats were used. Bilateral guide cannulae were implanted into the ventral NAc shell as above and a stainless steel monopolar stimulating electrode (Plastics One) was then implanted into the right medial forebrain bundle at an angle 10 degrees posterior to the normal ( $-4.2 \mathrm{~mm}$ posterior from bregma, $1.7 \mathrm{~mm}$ lateral from midline, and $-7.9 \mathrm{~mm}$ ventral to dura). The electrodes were coated with polyamide insulation except at the tip. A noninsulated stainless steel wire was used as the anode and wrapped around a stainless steel screw embedded in the skull. Finally, the electrode and both cannulae were fixed in place with three additional skull screws and acrylic cement. All animal procedures were approved by the Institutional Animal Care and Use Committee of McLean Hospital in strict accordance with the National Institutes of Health's Guide for the Care and Use of Laboratory Animals (2002).

Drugs. NBQX disodium salt, AMPA hydrobromide, and 1-naphthylacetyl spermine trihydrochloride (NASPM) were obtained from Sigma-Aldrich. Naloxone was dissolved in $0.9 \%$ saline and administered subcutaneously to rats in a volume of $1 \mathrm{ml} / \mathrm{kg}$. Doses of naloxone used in place conditioning $(0.01 \mathrm{mg} / \mathrm{kg})$ and somatic withdrawal $(0.1 \mathrm{mg} / \mathrm{kg})$ experiments were based on our previous work showing a dosedependent dissociation between affective and somatic signs of morphine withdrawal (Chartoff et al., 2006b). The dose of naloxone used in ICSS $(0.3 \mathrm{mg} / \mathrm{kg})$ was determined empirically for this study (see below) and was the lowest dose that increased ICSS thresholds significantly. NBQX, AMPA, and NASPM were dissolved in ultra-pure distilled water and administered intracranially. Intracranial microinjections were administered using a syringe pump and $10 \mu \mathrm{l}$ Hamilton syringes connected to polyethylene tubing, which was fitted to a bilateral injector stylette (33gauge; Plastics One) extending $1.0 \mathrm{~mm}$ beyond the end of the cannula. All animals received $0.5 \mu \mathrm{l} /$ side bilateral infusions at a rate of $0.2 \mu \mathrm{l} / \mathrm{min}$. Each infusion was followed by a 3 min period to allow for diffusion of drug before removing injector stylettes.

Placebo and morphine pellets (75 mg of morphine base/pellet) were obtained from the National Institute of Drug Abuse, National Institutes of Health (Bethesda, MD). Rats were made dependent on morphine by subcutaneous implantation of two morphine pellets (or two placebo pellets for control) while under isoflurane anesthesia, as described previously (Chartoff et al., 2006b). The wounds were closed with two stainless-steel skin clips and a triple-antibiotic ointment was applied.

Locomotor activity. To determine behaviorally relevant, optimal doses of intra-NAc shell AMPA and NBQX, three locomotor activity experiments were conducted, each with a separate cohort of rats. Experiment 1 (see Fig. $1 A, 16$ rats) tested the effects of intra-NAc shell AMPA (0.0, 0.03, $0.1,0.3 \mu \mathrm{g} / \mathrm{side}$ ), Experiment 2 (see Fig. $1 B, n=19$ rats) tested the effects of intra-NAc shell NBQX $(0.0,0.1,0.3,1.0 \mu \mathrm{g} / \mathrm{side})$, and Experiment 3 (see Fig. $1 C, n=10$ rats) tested the effects of coadministered NBQX (0.0, $0.1 \mu \mathrm{g} / \mathrm{side})$ and AMPA $(0.0,0.1 \mu \mathrm{g} / \mathrm{side})$. In Experiments 1 and 3, rats were tested once with each dose of drug administered in random order. In Experiment 2, 10 rats were exposed to each dose of NBQX and an additional 9 rats were tested with only NBQX $(0.0,0.3 \mu \mathrm{g} / \mathrm{side})$. Test days were separated by $2-3 \mathrm{~d}$ of no treatment. Before each drug test, rats were placed in automated $43.2 \times 43.2 \times 30.5 \mathrm{~cm}(\mathrm{~L} \times \mathrm{W} \times \mathrm{H})$ activity chambers (Med Associates) for $1 \mathrm{~h}$ to habituate and then activity was recorded. After habituation, rats were removed from the activity chambers and AMPA, NBQX, or vehicle was microinjected into the NAc shell as described above. Rats were immediately placed back in the activity chambers and locomotor activity was recorded for an additional hour. The total number of activity counts (photocell beam breaks) during the test sessions was quantified in 5 min bins and converted to distance traveled in centimeters. Differences among treatment groups were analyzed using a two-way repeated-measures 
ANOVA (treatment $\times$ time). Significant effects were analyzed using Bonferroni's multiple-comparisons post hoc tests.

Place conditioning. For place-conditioning studies, an unbiased, threecompartment place-conditioning apparatus (Med Associates) was used in which each compartment differed in floor texture (metallic rods or mesh), wall coloring (black or white), and lighting (dim or bright intensity), as described previously (Chartoff et al., 2006b). On day 0, rats were allowed to explore all three compartments freely for $30 \mathrm{~min}$ to test for inherent bias for any of the three compartments ("screening"). Rats that showed strong a priori preferences ( $\geq 18 \mathrm{~min}$ ) for a compartment during the screening period were eliminated from the study. The remaining rats $(\geq 90 \%)$ underwent surgery for implantation of intra-NAc shell cannulae $24 \mathrm{~h}$ after screening. In Experiment 1 (see Fig. $2 A ; n=7-12$ rats/ AMPA dose), the effects of intra-NAc shell AMPA were tested on place conditioning, using 2 place-conditioning sessions in $1 \mathrm{~d}$. In the morning conditioning session (10:00 A.M.), rats received an intra-NAc shell microinjection of water and were confined to one side of the placeconditioning apparatus for $1 \mathrm{~h}$. In the afternoon conditioning session (2:00 P.M.), rats received intra-NAc shell microinjections of AMPA $(0.03,0.1,0.3 \mu \mathrm{g} / \mathrm{side})$ and were confined to the other side chamber for $1 \mathrm{~h}$. The following day, rats were allowed to freely explore all three compartments in a 30 min "test" session (12:00 P.M.). In Experiment 2 (see Fig. $2 B ; n=5-10$ rats per treatment group), the effects of intra-NAc shell NBQX were tested on morphine-withdrawal-induced conditioned place aversions. Rats were implanted subcutaneously with either morphine or placebo pellets 5 or $6 \mathrm{~d}$ after stereotactic cannula surgery. Three days after pellet implantation, when dependence had developed (Gold et al., 1994; Chartoff et al., 2006b), they were conditioned in two separate sessions. In the morning (10:00 A.M.), rats received an intra-NAc shell microinjection of water followed immediately by a subcutaneous injection of $0.9 \%$ saline and were then confined to one side of the place-conditioning apparatus for $1 \mathrm{~h}$. In the afternoon (2:00 P.M.), rats received intra-NAc shell microinjections of $\operatorname{NBQX}(0.0,0.1 \mu \mathrm{g} /$ side $)$, followed by a subcutaneous injection of saline or naloxone $(0.01 \mathrm{mg} / \mathrm{kg})$ and were then confined to the other side chamber for $1 \mathrm{~h}$. The following day, rats were allowed to explore all three compartments freely in a $30 \mathrm{~min}$ "test" session (12:00 P.M.). In both experiments, data are expressed as a change score: [time spent in the drug-paired side minus time spent in the vehicle side after conditioning (testing)] minus [time spent in the drug-paired side minus time spent in the vehicle side before conditioning (screening)]. Data were analyzed using a two-way ANOVA [treatment $\times$ conditioning] with repeated measures on conditioning (before vs after conditioning). Significant effects were followed by Bonferroni's multiple-comparisons post hoc tests.

Somatic withdrawal. Subsets of morphine-dependent $(n=11)$ and nondependent $(n=8)$ rats used in the preceding place-conditioning experiments were subsequently used for somatic withdrawal testing $(6 \mathrm{~d}$ after morphine or placebo pellet implantation). On the first day of the somatic withdrawal procedure, rats were habituated to the scoring environment: clear, $65-\mathrm{cm}$-high by $25-\mathrm{cm}$-diameter Plexiglas cylinders that contained a small amount of bedding in a quiet, temperature-maintained $\left(20^{\circ} \mathrm{C}\right)$ room. Rats were placed in the cylinders for $15 \mathrm{~min}$, injected subcutaneously with vehicle ( $0.9 \%$ saline) and returned to the cylinders for another $15 \mathrm{~min}$. The next day, an experimental treatment was administered. The rats were placed in the cylinders for $15 \mathrm{~min}$ and then treated with intra-NAc shell NBQX $(0.1 \mu \mathrm{g} / \mathrm{side})$ or vehicle, subcutaneous naloxone $(0.1 \mathrm{mg} / \mathrm{kg})$ or vehicle, or a combination of NBQX and naloxone. Every other day, for a total of $3 \mathrm{~d}$, each rat was exposed to 1 of the 3 treatments presented in random order. This experimental design is similar to that used previously for examination of the effects of intracranial administration of the dopamine D1 receptor agonist SKF 82958 on somatic withdrawal (Chartoff et al., 2009). Rats were placed back in the cylinders immediately after drug treatments and somatic withdrawal behaviors were scored for $15 \mathrm{~min}$ by an observer who was unaware of the treatments. The following behaviors were marked as either present or absent: diarrhea, ptosis, chromodacyrrhea (reddish-brown discharge from the eyes or nose), penile erection, and irritability to touch. The frequency of the following behaviors was quantified: jumping, cage crossing, rearing, digging, flat posture, "wet dog shakes," grooming, and teeth chattering. This protocol is a modification of that described previously (Chartoff et al., 2006b; Chartoff et al., 2009). Somatic withdrawal behaviors are reported for the individual behaviors wet dog shakes and cage crossings and for the total of all behaviors. Data were analyzed using a two-way repeated-measures ANOVA (treatment $\times$ withdrawal sign) with Bonferroni's multiple-comparisons post hoc tests.

ICSS. After 1 week of recovery from stereotactic cannula and ICSS electrode surgery, rats were trained to respond for brain stimulation using a continuous reinforcement schedule (FR1) at $141 \mathrm{~Hz}$, in which each lever press earned a $500 \mathrm{~ms}$ train of square-wave cathodal pulses (100 ms per pulse), as described previously (Carlezon and Chartoff, 2007). The delivery of the stimulation was accompanied by illumination of a $2 \mathrm{~W}$ house light. The stimulation current was adjusted (final range: $180-240 \mu \mathrm{A}$ ) for each rat to the lowest value that would sustain a reliable rate of responding (at least 40 lever presses per $50 \mathrm{~s}$ ). After the minimal effective current was found for each rat, it was kept constant throughout training and testing.

Rats were then trained on series of 15 descending stimulation frequencies (141-28 Hz, in $0.05 \log _{10} \mathrm{~Hz}$ increments). Each series of frequencies comprised $1 \mathrm{~min}$ trials at each frequency. Each $1 \mathrm{~min}$ trial included a $5 \mathrm{~s}$ period during which noncontingent stimuli were given $(1 / \mathrm{s})$ at the next available stimulation frequency, a 50 s test period during which the number of responses was counted and a $5 \mathrm{~s}$ period during which no stimulation was available. Each $500 \mathrm{~ms}$ stimulation train in a trial was followed by a $500 \mathrm{~ms}$ timeout. All responses were counted. After responding had been evaluated at each of the 15 frequencies, another series of identical frequencies was started. To characterize the functions relating response strength to reward magnitude (rate-frequency function), a least-squares line of best fit was plotted across the frequencies that sustained responding at $20 \%, 30 \%, 40 \%, 50 \%$, and $60 \%$ of the maximum rate using customized analysis software. The stimulation frequency at which the line intersected the $x$-axis (theta 0 ) was defined as the ICSS threshold (Carlezon and Chartoff, 2007). This is considered the theoretical point at which the stimulation becomes reinforcing. Rats were trained until mean ICSS thresholds remained stable ( $\pm 10 \%$ for 4 consecutive days).

In each ICSS experiment, 3 rate-frequency functions $(3 \times 15 \mathrm{~min})$ were determined for each rat immediately before drug treatment. The first function served as a "warm-up" and was discarded because it tends to be variable. The ICSS thresholds for the second and third functions were averaged and served as baseline thresholds. Immediately after drug treatments, four more $15 \mathrm{~min}$ rate frequency functions were obtained (60 min total). Data are expressed as percentage of pre-drug baseline thresholds. In Experiment 1 (see Fig. $4 A ; n=6$ rats), the effects of subcutaneous naloxone on brain stimulation reward were determined in morphinedependent rats. Rats were made dependent on morphine by subcutaneous implantation of morphine pellets $(2 \times 75 \mathrm{mg})$ as described above. Starting $3 \mathrm{~d}$ after pellet implantation, rats were treated every other day with naloxone $(0.01,0.03,0.1,0.3 \mathrm{mg} / \mathrm{kg}, \mathrm{SC})$ or vehicle. Each rat received each dose in random order. In Experiment 2 (see Fig. $4 B ; n=5$ rats), the effects of intra-NAc shell NBQX on brain stimulation reward were determined in nondependent rats. On each experimental day, rats received intra-NAc shell injections of NBQX $(0.03,0.1,0.3,1.0 \mu \mathrm{g} /$ side $)$ or vehicle. Experimental days were separated by $2 \mathrm{~d}$, during which $1 \mathrm{~h}$ ICSS maintenance sessions were run but no drug treatments were given. Each rat received each drug dose in random order. In Experiment 3 (see Fig. $4 C-E ; n=5$ rats), the effects of intra-NAc shell NBQX on naloxoneinduced changes in ICSS behavior in morphine-dependent rats was measured. Morphine-dependent rats were microinjected with NBQX $(0.0$, $0.1 \mu \mathrm{g} / \mathrm{side})$ and naloxone $(0.0,0.3 \mathrm{mg} / \mathrm{kg}, \mathrm{SC})$ and immediately placed back in the ICSS chambers for the 60 min test session. In Experiment 4 (see Fig. $8 A ; n=6$ rats), the dose-response effects of intra-NAc shell NASPM on brain stimulation reward were determined in nondependent rats. On each experimental day, rats received intra-NAc shell injections of NASPM $(0.0,1.0,5.0,25.0 \mu \mathrm{g} /$ side $)$. Experimental days were separated by $2 \mathrm{~d}$, during which $1 \mathrm{~h}$ ICSS maintenance sessions were run but no drug treatments were given. Each rat received each drug dose in random order. In Experiment 5 (see Fig. $8 B-D ; n=5$ rats), the effects of intra-NAc shell NASPM on naloxone-induced changes in ICSS behavior in morphinedependent rats was measured. Morphine-dependent rats were microin- 

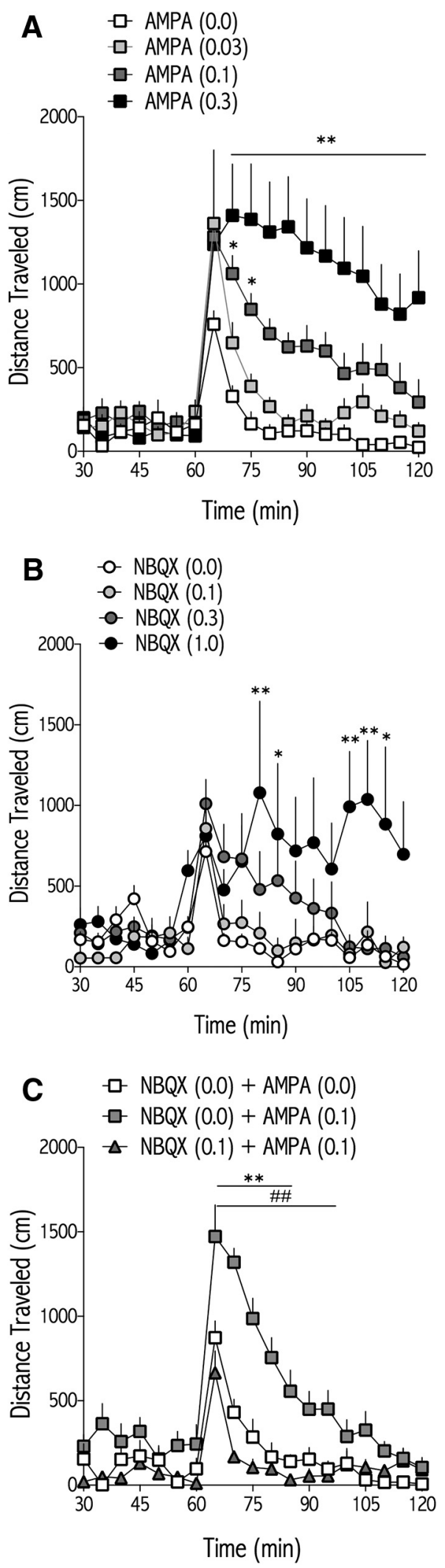

Figure 1. Dose-response effects of intra-NAc shell AMPA, NBQX, and NBQX + AMPA on locomotor activity over time. Rats were habituated in the activity chambers for $60 \mathrm{~min}$ before drug delivery. At $t=60 \mathrm{~min}$, rats were removed from the chambers and drug was microinjected into the NAc shell. Rats were administered AMPA $(0.0,0.03,0.1,0.3 \mu \mathrm{g} / \mathrm{side}$ in randomized order; $n=16 ; \boldsymbol{A}), \operatorname{NBQX}(0.0,0.1,0.3,1.0 \mu \mathrm{g} /$ side in randomized order; $n=7-14 ; \boldsymbol{B})$, or a mixture $(n=10)$ of NBQX $(0.0,0.1 \mu \mathrm{g} /$ side) and AMPA $(0.0,0.1 \mu \mathrm{g} / \mathrm{side})(C)$ in randomized order and locomotor activity was recorded immediately afterward for $60 \mathrm{~min}$. Data are jected with NASPM $(0.0,5.0 \mu \mathrm{g} / \mathrm{side})$ and naloxone $(0.0,0.3 \mathrm{mg} / \mathrm{kg}, \mathrm{SC})$ and immediately placed back in the ICSS chambers for the 60 min test session. Drug treatment days were separated by $2 \mathrm{~d}$, during which no drug treatments were given but $1 \mathrm{~h}$ ICSS maintenance sessions were run to ensure that the rats had recovered from prior treatment and that their ICSS thresholds remained within $10 \%$ of their original baseline values. Prior studies have shown that repeated, consistent testing can be done in ICSS (Carlezon and Chartoff, 2007) and in morphine-dependent rats (Chartoff et al., 2006b; Chartoff et al., 2009) given that plasma levels of morphine are stable between 3 and $12 \mathrm{~d}$ after subcutaneous implantation of two morphine pellets (Gold et al., 1994). Data were analyzed with one-way, repeated-measures ANOVA or two-way repeated-measures ANOVA (treatment $\times$ time). Significant effects were followed with Bonferroni's multiple-comparisons post hoc tests.

Histology. After testing, rats were overdosed with pentobarbital (130 $\mathrm{mg} / \mathrm{kg}, \mathrm{IP}$ ) and perfused intracardially with $0.9 \%$ saline followed by $4 \%$ paraformaldehyde. The brains were removed from the skull and immersed in the fixative for $20 \mathrm{~h}$ at $4^{\circ} \mathrm{C}$. After fixation, the brains were stored for $4 \mathrm{~d}$ in $20 \%$ glycerol, $0.1 \mathrm{~m}$ PBS, pH 7.4, and then $40 \mu \mathrm{m}$ sections were cut through the NAc. Sections were cresyl violet stained for histological analysis of cannula placements. Rats with cannula placements outside of the target zones were excluded from analyses. Because drug microinjections have a tendency to travel up the guide cannula track (Wise and Hoffman, 1992), we used rats in which the bilateral guide cannula placements were dorsal to the NAc shell (including vertex of NAc and lateral septum) as a control group, as described previously (Chartoff et al., 2009), for the effects of NBQX on naloxone-induced conditioned place aversions (see Fig. $2 B$, inset). ICSS electrode placements were not examined because we have substantial empirical evidence that electrodes are consistently placed in the target area of the medial forebrain bundle at the level of the lateral hypothalamus only in rats that learn to press reliably (Todtenkopf et al., 2004; Todtenkopf et al., 2006; Carlezon and Chartoff, 2007; Tomasiewicz et al., 2008; Ebner et al., 2010). Likewise, any rat that does not learn to press for rewarding brain stimulation has consistently had an electrode placement outside of this area.

$B S^{3}$ protein cross-linking. To assess intracellular versus surface expression of AMPAR subunits, a Bis(sulfosuccinimidyl)suberate $\left(\mathrm{BS}^{3}\right)$ protein cross-linking approach was used in separate cohorts of rats that were implanted with placebo $(n=20$ rats $)$ or morphine $(2 \times 75 \mathrm{mg} ; n=20$ rats) pellets as described above. Three days after pellet implants, rats were injected subcutaneously with naloxone $(1.0 \mathrm{mg} / \mathrm{kg})$ or vehicle and killed by decapitation 30 min later. Brains were removed and the whole NAc was immediately dissected out in a flat glass culture dish with a $1 \mathrm{~mm}$ punch tool on ice. NAc samples were then finely chopped with a doubleedge razor and immediately placed in $1.5 \mathrm{ml}$ Eppendorf tubes containing $40 \mu \mathrm{l}$ of $\mathrm{BS}^{3}$ (Thermo Scientific, 21580) in $1 \mathrm{ml}$ of artificial CSF as described previously (Boudreau et al., 2012). Tubes were shaken gently and placed in a rocker in a cold room $\left(4^{\circ} \mathrm{C}\right)$. After $30 \mathrm{~min}$, the $\mathrm{BS}^{3}$ cross-linking reaction was quenched by adding $100 \mu \mathrm{l}$ of $1 \mathrm{M}$ glycine and rocking for $10 \mathrm{~min}$ in the cold room. Samples were then centrifuged for 2 $\min$ at $20,000 \times g$. The supernatant was discarded and the pellet resuspended in $400 \mu \mathrm{l}$ of lysis buffer containing the following (in $\mathrm{mM}$ ): 25 HEPES, pH 7.4, $500 \mathrm{NaCl}, 2 \mathrm{NaCl}, 1 \mathrm{DTT}, 1 \mathrm{PMSF}$, and $20 \mathrm{NaF}$ plus $1 \times$ protease inhibitor mixture (Calbiochem, 539131), 0.1\% (v/v) Nonidet P-40, $1 \mu \mathrm{M}$ okadaic acid, $1 \mu \mathrm{M}$ Microsystin-LF, and $1 \mathrm{~mm}$ sodium orthovandadate, and then sonicated for $5 \mathrm{~s}$ at medium power. Tubes were centrifuged for $2 \mathrm{~min}$ at $20,000 \times g$ and the supernatant was collected (the pellet was discarded), aliquoted into $40 \mu \mathrm{l}$ volumes, and stored at $-80^{\circ} \mathrm{C}$ until gel electrophoresis and Western blotting.

Protein fractionation. To further examine subcellular trafficking of AMPAR subunits in response to morphine dependence and withdrawal,

$\leftarrow$

expressed as mean distance traveled (in centimeters) in 15 min increments \pm SEM. ${ }^{*} p<0.05$, ${ }^{* *} p<0.01$, comparing indicated treatment and time point with corresponding time point of vehicle group; \#\#p $<0.01$ comparing NBQX (0.0 $\mu \mathrm{g} / \mathrm{side})+$ AMPA $(0.1 \mu \mathrm{g} / \mathrm{side})$ with NBQX (0.1 $\mu \mathrm{g} / \mathrm{side})+$ AMPA $(0.1 \mu \mathrm{g} / \mathrm{side})$. 
a protein fractionation approach was taken using separate cohorts of rats that were implanted with placebo ( $n=20$ rats) or morphine $(2 \times 75$ mg; $n=20$ rats) pellets as described above. Three days after pellet implants, rats were injected with naloxone $(1.0 \mathrm{mg} / \mathrm{kg}, \mathrm{SC})$ or vehicle and killed by decapitation 30 min later. Brains were rapidly removed and frozen in isopentane kept on dry ice. Brains were then sliced on a cryostat (Microm, HM $505 \mathrm{E}$ ) kept at $-20^{\circ} \mathrm{C}$ until the NAc was exposed $(1.7 \mathrm{~mm}$ anterior to bregma). Bilateral tissue punches $\left(\sim 1 \mathrm{~mm}^{3}\right)$ were taken of the NAc (core and shell combined) and the caudate-putamen $(\mathrm{CPu})$ and placed in Eppendorf tubes kept on dry ice. Biochemical fractionation was performed using protocols described previously (Dunah and Standaert, 2001; Hallett et al., 2008) with modifications. Tissue punches were homogenized (TissueRuptor; Qiagen) for $20 \mathrm{~s}$ in 0.8 (NAc) or 1.0 (dorsal striatum) $\mathrm{ml}$ of ice-cold TEVP (10 mM Tris base, $5 \mathrm{~mm} \mathrm{NaF}, 1 \mathrm{~mm} \mathrm{Na} \mathrm{VO}_{4}, 1 \mathrm{~mm}$ EDTA, 1 mм EGTA, pH 7.4) plus 320 mm sucrose buffer in $4 \mathrm{ml}$ culture tubes. A $100 \mu \mathrm{l}$ aliquot of this homogenate $(\mathrm{H}$, total homogenate) was transferred to an Eppendorf tube and saved. The remainder of homogenate $(\mathrm{H})$ was centrifuged at $800 \times g$ for $10 \mathrm{~min}$ at $4^{\circ} \mathrm{C}$. The pellet (P1, nuclei, and large debris) was resuspended in $200 \mu$ l of TEVP buffer and saved. The supernatant (S1) was removed and placed in a clean Eppendorf tube on ice. S1 was centrifuged at $9200 \times g$ for $15 \mathrm{~min}$ at $4^{\circ} \mathrm{C}$. Supernatant (S2) was collected and centrifuged at $165,000 \times g$ for $2 \mathrm{~h}$ to generate a pellet (P3, light membranes, recycling endosomes) that was resuspended in TEVP $(100 \mu \mathrm{l})$ and saved. The pellet obtained from centrifuging S1 (P2, crude synaptosomal membranes) was rinsed once in TEVP plus $35.6 \mathrm{~mm}$ sucrose buffer and then resuspended in $250 \mu \mathrm{l}$ of TEVP buffer and saved. All saved samples were kept at $-80^{\circ} \mathrm{C}$ until PAGE.

Gel electrophoresis and Western blotting. For all samples, protein content was determined using the Bio-Rad DC Protein Assay kit. For fractionated samples, the concentration of each sample was adjusted to $0.3 \mathrm{mg} / \mathrm{ml}$ protein. NuPAGE lithium dodecyl sulfate sample buffer (Invitrogen) and $50 \mathrm{~mm}$ dithiothreitol were added to each sample before heating at $70^{\circ} \mathrm{C}$ for $10 \mathrm{~min}$. To load equivalent amounts of protein for each fraction, $3 \mu \mathrm{g}$ of each fractionated sample (Fractions H, P2, and P3) were loaded into NuPAGE Novex $4-12 \%$ Bis-Tris gels (Invitrogen) for separation by PAGE. SeeBlue Plus 2 (Invitrogen) prestained standards were run for molecular weight estimation. For $\mathrm{BS}^{3}$ cross-linked samples, sample concentrations were adjusted to $2.5 \mathrm{mg} / \mathrm{ml}$. Twenty micrograms of each sample was loaded into $4-15 \%$ Tris-Cl mini-Protean gels (Bio-Rad) using the Mini-PROTEAN Tetra Cell (Bio-Rad) and Bio-Rad Tris/Glycine/SDS running buffer. HiMark prestained standard (Invitrogen) and SeeBlue Plus2 prestained standard (Invitrogen) served as molecular weight standards. Gels ran at room temperature at constant $200 \mathrm{~V}$ until loading dye escaped the foot of gel, $\sim 30-40 \mathrm{~min}$. Proteins were subsequently transferred to PVDF membrane (PerkinElmer Life Sciences).

For $\mathrm{BS}^{3}$ cross-linked samples, PVDF membranes were blocked in 5\% nonfat dry milk in TBS (1 L 10×: $200 \mathrm{~mm}$ Tris Base, $1370 \mathrm{~mm} \mathrm{NaCl}, \mathrm{pH}$ $7.4)$ and $0.05 \%(\mathrm{v} / \mathrm{v})$ Tween 20 (TBS-T) for $2 \mathrm{~h}$ at room temperature. Blots were then washed once in TBS-T, cut with a razor at appropriate molecular weights for probing, and incubated in TBS-T with primary

\section{C}
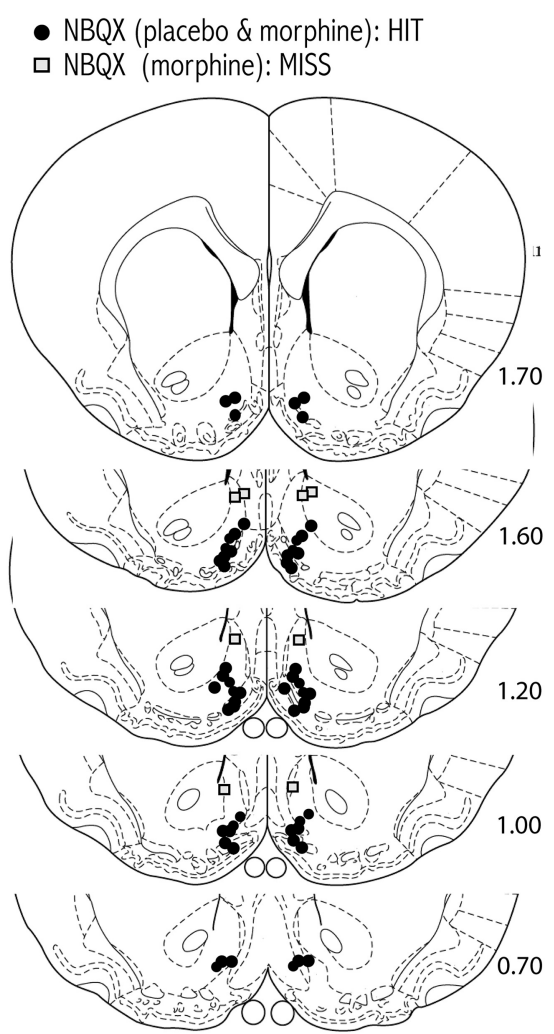

Figure 2. Administration of AMPA into the NAc shell produces, whereas the AMPAR antagonist NBQX blocks, conditioned place aversions. $\boldsymbol{A}$, Nondependent rats with bilateral cannulae in the NAc shell underwent conditioning with AMPA $(0.03,0.1,0.3$ $\mu \mathrm{g} / \mathrm{side} ; n=7-12)$. $\boldsymbol{B}$, Rats with bilateral cannulae in the NAc shell were implanted with placebo $(n=19)$ or morphine $(n=23)$

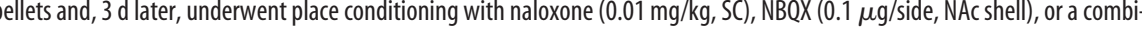
control regions are shown in the inset. Data are expressed as the change in time spent in the drug-paired side after conditioning drug-paired chamber after conditioning compared with before conditioning are indicated with ${ }^{*} p<0.05$. $\boldsymbol{C}$, Microinjection placements from NBQX-treated rats included in $\boldsymbol{B}$ and the inset in $\boldsymbol{B}$ (filled circles, NAc shell "hit"; gray squares, NAc shell "miss"). Numbers to the right of atlas plates indicate millimeters from bregma (Paxinos, 1995).

antibody (1:1000, rabbit anti-GluA1, PA1-37776, Thermo Scientific; 1:500, mouse anti-GluA2, Neuromab, 75-002; 1:20,000, rabbit antiactin, Sigma-Aldrich, A-5060) at $4^{\circ} \mathrm{C}$ overnight on an orbital shaker.

For fractionated samples, nonspecific binding sites on the PVDF membranes were blocked for $2 \mathrm{~h}$ at room temperature in blocking buffer containing 5\% nonfat dry milk in PBS and 0.02\% Tween 20 (PBS-T). Blots were then incubated in primary antibody $(1: 1000$, rabbit antiGluA1, AB1504, Millipore; 1:1000, rabbit anti-P-GluA1 $\left(\mathrm{Ser}^{845}\right)$, 041073, Millipore; 1:1000, rabbit anti-GluA2, AB1768, Millipore; 1:1000, anti-PSD-95, AB9634, Millipore; 1:1000, anti-transferrin receptor (antiTfR, 13-6800, Invitrogen; 1:500, goat anti-calnexin, MAB3126, Millipore; 1:1000, rabbit anti-stargazin, AB9876, Millipore; and 1:5000, monoclonal anti-tubulin, T4026, Sigma-Aldrich). To probe each blot with multiple antibodies, blots were cut into three parts: high $(>80 \mathrm{kDa})$, medium $(46-80 \mathrm{kDa})$, and low $(<46 \mathrm{kDa})$ molecular weights, and each part was probed with an antibody that recognized a protein within that weight range. Apparent molecular weights for the antibodies used are as follows: GluA1, P-GluA1, GluA2, $100 \mathrm{kDa}$; PSD-95, $95 \mathrm{kDa}$; calnexin, $\sim 67 \mathrm{kDa}$; tubulin, $55 \mathrm{kDa}$; and stargazin, $\sim 37 \mathrm{kDa}$. After probing high- 

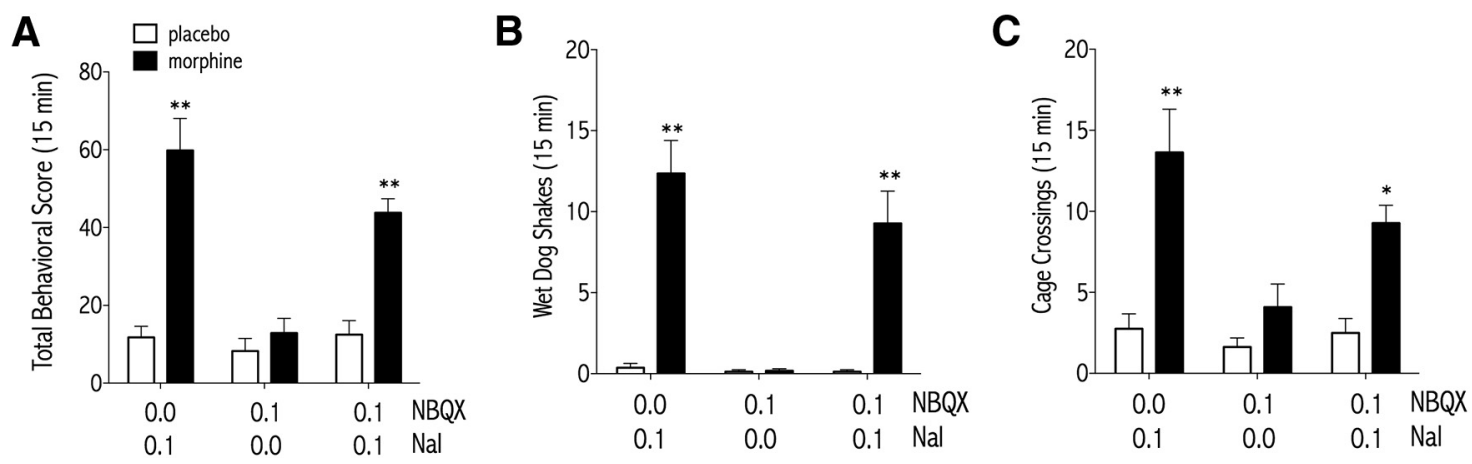

Figure 3. Administration of the AMPAR antagonist NBQX into the NAc shell does not affect somatic withdrawal signs in morphine-dependent rats. A subset of rats with bilateral cannulae in the NAc shell that had been implanted with placebo $(n=8)$ or morphine $(n=13)$ pellets and used in place conditioning were used to test the effects of NBQX on naloxone-induced somatic withdrawal signs. After a 15 min habituation period in the observation chambers, rats were administered NBQX (0.1 $\mu \mathrm{g} / \mathrm{side}$, NAc shell), naloxone (0.1 mg/kg, SC), or a combination of intra-NAc shell NBQX and systemic naloxone. Rats were placed back in the chambers and somatic withdrawal signs were measured for $15 \mathrm{~min}$. Data are expressed as the mean \pm SEM occurrence of all somatic withdrawal signs $(\boldsymbol{A})$, wet dog shakes $(\boldsymbol{B})$, and cage crossings $(\boldsymbol{C}){ }^{*} p<0.05,{ }^{* *} p<0.01$ compared with placebo controls of the same acute drug treatment.

weight-range blots for P-GluA1, they were stripped of antibodies by incubation with stripping buffer $(62.5 \mathrm{~mm}$ Tris, $2 \%$ SDS, $100 \mathrm{~mm}$ $\beta$-mercaptoethanol, $\mathrm{pH} 6.8$ ) for $2 \times 15 \mathrm{~min}$ at $50^{\circ} \mathrm{C}$. Blots were subsequently reblocked and probed with anti-GluA2 or anti-PSD-95. Medium weight range blots were stripped and reprobed with anti-tubulin as a loading control.

For all samples, blots were washed and placed in 5\% milk in TBS-T with anti-rabbit- (Vector Laboratories, PI-1000) or anti-mouse (Vector Laboratories, PI-1000) peroxidase-labeled secondary antibody for $2 \mathrm{~h}$ at room temperature. Blots were washed $4 \times 5 \mathrm{~min}$ in TBS-T and then developed using Western Lightning Plus ECL (PerkinElmer) on a Kodak Image Station 4000. Protein immunoblots were analyzed using Carestream Molecular Imaging Software, version 5.0. Development times for each antibody were kept consistent across all blots, allowing for comparisons between blots. Net intensity (the sum of the pixels within the band of interest minus the sum of the background pixels) was determined for each band of interest. Data are expressed as the mean net intensity of the protein of interest normalized to the net intensity of tubulin for each fractionated sample or to the net intensity of actin for each cross-linked sample \pm SEM. Data from cross-linked samples were analyzed using one-way ANOVAs. Significant effects were followed with Bonferroni's multiplecomparisons post hoc tests. Data from fractionated samples were analyzed using a two-way ANOVA (treatment $\times$ fraction) with repeated measures on fractions.

\section{Results}

Dose-dependent effects of intra-NAc shell NBQX on AMPAinduced locomotor activity

To determine behaviorally relevant, optimal doses of intra-NAc shell AMPA and NBQX, the drugs were microinjected through bilateral guide cannulae into the NAc shell and locomotor activity was monitored for $1 \mathrm{~h}$. Two-way repeated-measures ANOVA showed significant treatment $X$ time interactions for the effects of AMPA alone (Fig. $1 A ; F_{(54,1080)}=4.90, p<0.001$ ), NBQX alone (Fig. $\left.1 B ; F_{(54,666)}=2.34, p<0.001\right)$, and NBQX $(0.1 \mu \mathrm{g} /$ side) plus AMPA $\left(0.1 \mu \mathrm{g} / \mathrm{side}\right.$ ) (Fig. $1 C ; F_{(36,486)}=2.34, p<$ $0.001)$. Post hoc analysis showed that rats treated with AMPA $(0.3$ $\mu \mathrm{g} / \mathrm{side}$ ) had greater locomotor activity for the entire $1 \mathrm{~h}$ test session and rats treated with AMPA $(0.1 \mu \mathrm{g} / \mathrm{side})$ had greater activity for the first $15 \mathrm{~min}$ of the test session compared with rats treated with intra-NAc shell vehicle. Post hoc analysis showed that rats treated with NBQX $(1.0 \mu \mathrm{g} / \mathrm{side})$ also had greater locomotor activity than vehicle-treated controls starting $20 \mathrm{~min}$ after drug infusion, although the effects were quite variable. Post hoc analysis in the combined drug experiment showed that AMPA (0.1 $\mu \mathrm{g} / \mathrm{side})$ significantly increased locomotor activity compared with vehicle treated controls for the first $25 \mathrm{~min}$ after drug infusion and NBQX (0.1 $\mu \mathrm{g} /$ side) blocked AMPA-induced locomotor activity. Based on these data, NBQX (0.1 $\mu \mathrm{g} /$ side $)$ was chosen as the dose to use for subsequent place-conditioning and ICSS studies because it completely blocked the locomotor-activating effects of AMPA without affecting locomotor activity on its own.

\section{Inhibition of NAc shell AMPARs blocks naloxone-induced conditioned place aversions in morphine-dependent rats}

To test the hypothesis that activation of AMPARs in the NAc shell is aversive, nondependent rats were conditioned with AMPA $(0.03,0.1,0.3 \mu \mathrm{g} / \mathrm{side})$. A two-way repeated-measures ANOVA revealed an interaction between treatment and conditioning (Fig. $\left.2 A ; F_{(2,23)}=4.04, p<0.05\right)$. Post hoc analysis showed that AMPA $(0.3 \mu \mathrm{g} / \mathrm{side})$ produced significant place aversions. The finding that this dose of AMPA was aversive and increased locomotor activity highlights prior work showing that aversive states can be associated with increased locomotor activity (Chartoff et al., 2006b; Chartoff et al., 2008).

To test the hypothesis that activation of AMPARs in the NAc shell is necessary for morphine-withdrawal-induced negativeaffective states, the AMPAR antagonist NBQX was microinjected into the NAc shell of morphine-dependent rats immediately before place conditioning with naloxone. A low dose of naloxone $(0.01 \mathrm{mg} / \mathrm{kg})$ was used to precipitate affective signs of morphine withdrawal selectively (Chartoff et al., 2006b; Chartoff et al., 2009). Two-way repeated-measures ANOVA demonstrated a significant effect of conditioning (pre vs post; Fig. $2 B ; F_{(1,37)}=5.65$, $p<0.05)$, with post hoc tests revealing that naloxone produced significant place aversions in morphine-dependent rats pretreated with intra-NAc shell vehicle but not NBQX $(0.1 \mu \mathrm{g} /$ side $)$. Intra-NAc shell microinjection of NBQX $(0.1 \mu \mathrm{g} / \mathrm{side})$ had no effect on its own in place conditioning and all treatments in placebo-implanted rats were motivationally neutral. To ensure that the ability of NBQX to block naloxone-induced place aversions was specific to effects in the NAc shell, place-conditioning data from morphine-dependent rats in which histological analysis showed cannulae placements in the vertex of the NAc, dorsal to the target area of the NAc shell (i.e., "misses") were analyzed. There was no significant difference between naloxone-induced place aversions in rats that received intra-NAc shell vehicle and those that received intracranial NBQX dorsal to the NAc shell (Fig. $2 B$ inset; $t_{(9)}=0.30, \mathrm{~ns}$ ). 
A

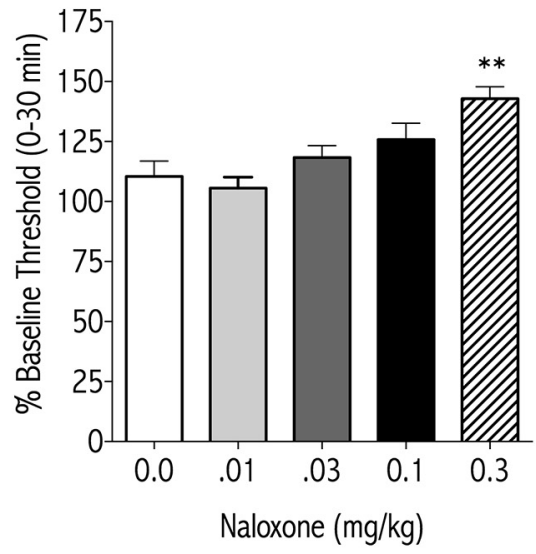

D

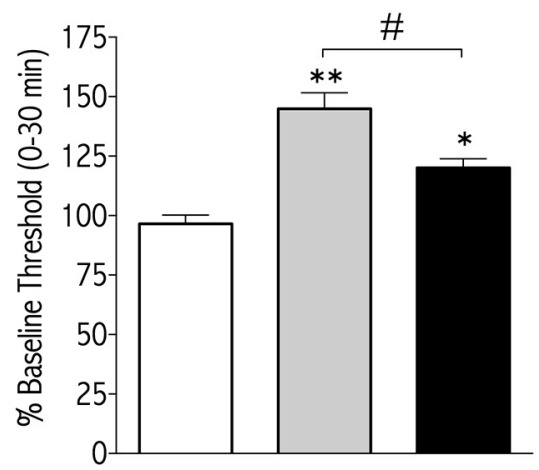

B

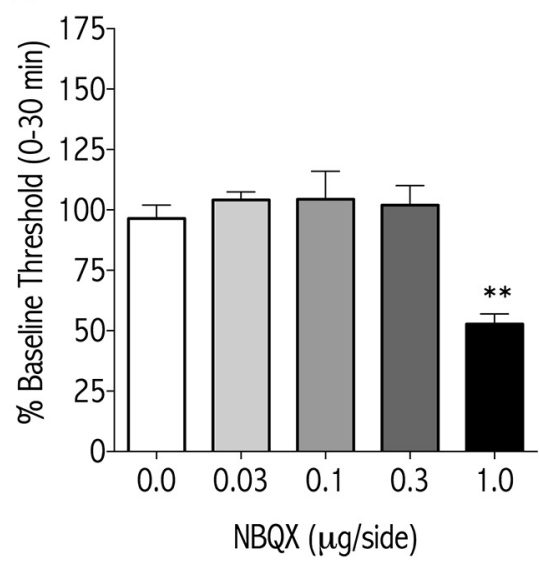

E

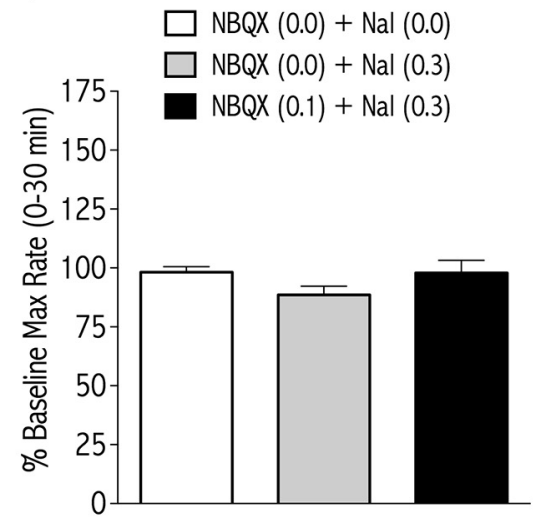

C

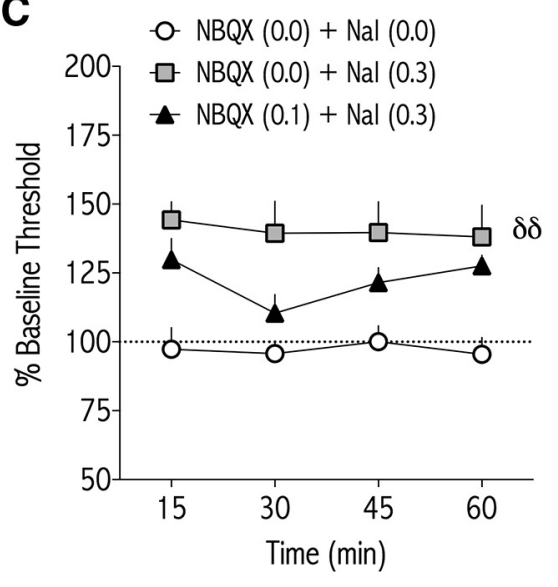

F

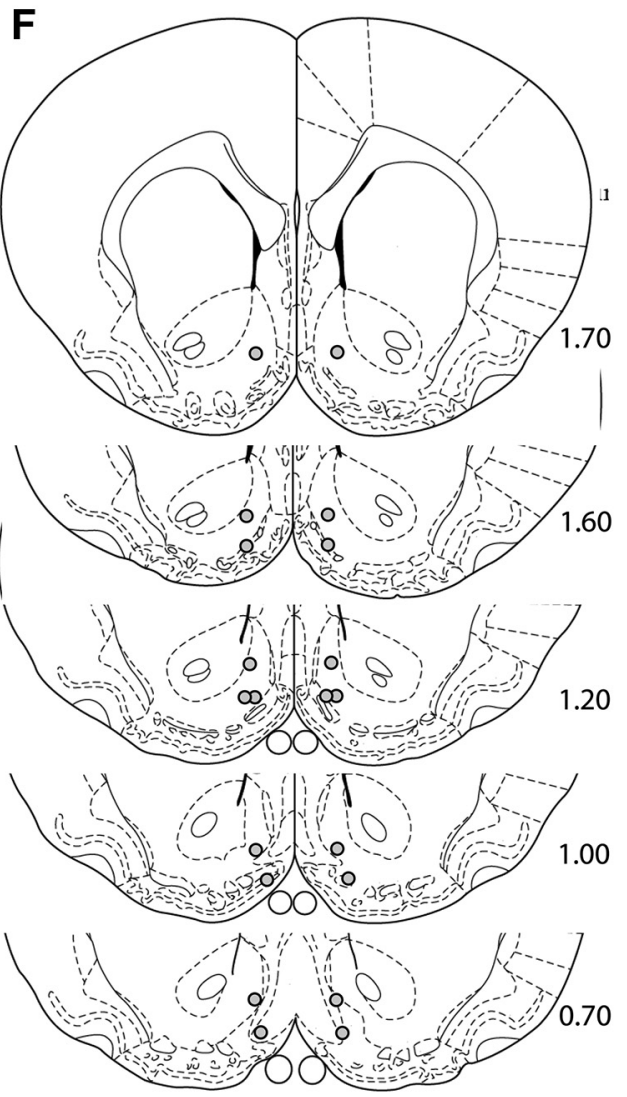


A

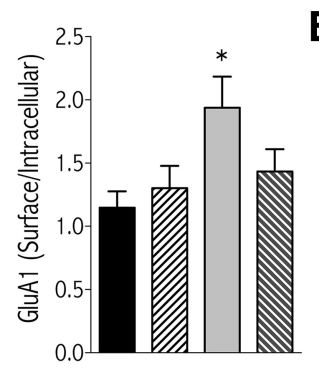

B

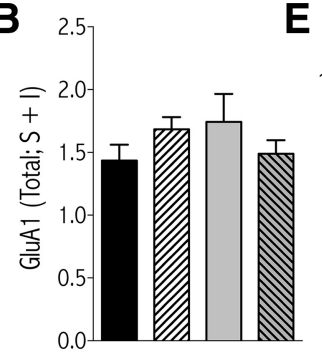

E

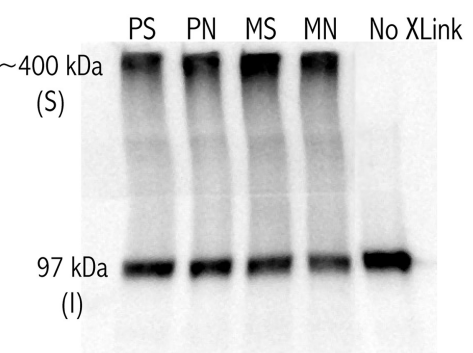

C
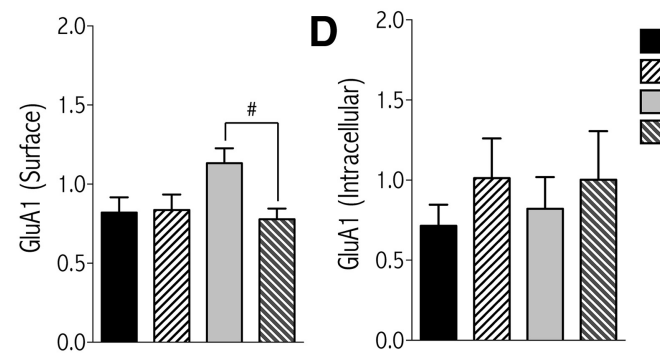

F

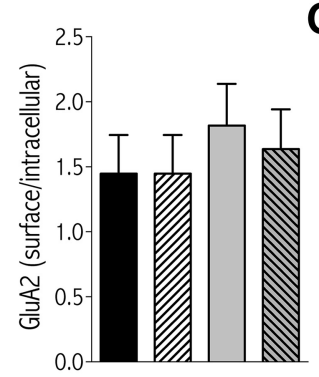

G

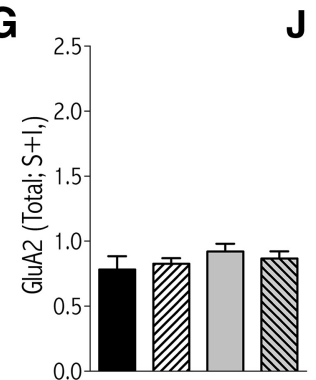

\section{J}

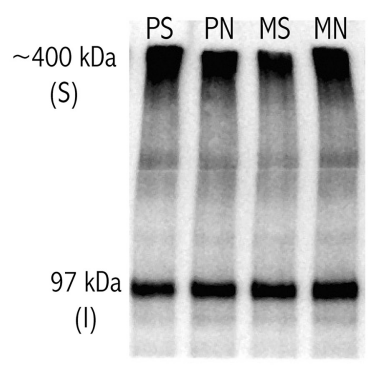

H

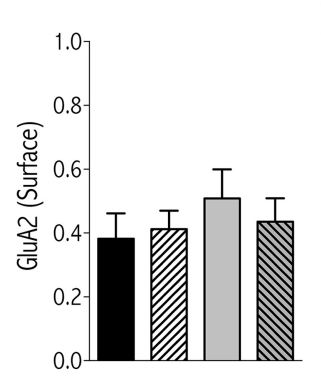

I

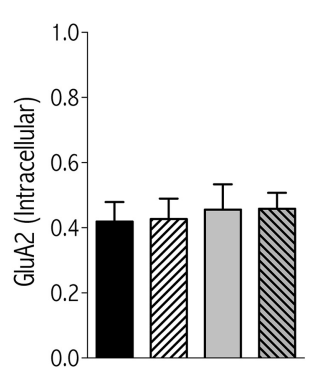

Placebo + Saline

Placebo + Naloxone

Morphine + Saline

Morphine + Naloxone
(I)

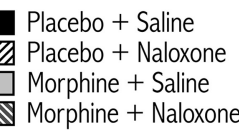

Placebo + Saline

Placebo + Naloxone

Morphine + Naloxone

Figure 5. $B S^{3}$ cross-linking of NAc tissue from morphine-dependent and nondependent rats shows that surface to intracellular ratios of GluA1, but not GluA2, are increased in morphine-dependent rats and returned to control levels 30 min after naloxone. $A$, $\boldsymbol{F}$, GluA1 S/I and GluA2S/I ratios, respectively. B, G, GluA1 and GluA2 total protein levels $(S+I)$, respectively. $\boldsymbol{C}, \boldsymbol{H}$, GluA1 and GluA2 surface levels (S), respectively. $\boldsymbol{D}, \boldsymbol{I}, \mathrm{GluA1}$ and GluA2 intracellular levels (I), respectively. $\boldsymbol{E}$, Representative Western blot for GluA1. Both high (surface-expressed) and monomeric (intracellular) molecular weight bands are detected in tissue from cross-linked tissue, whereas non-cross-linked (№ Xlink) tissue yields the monomeric molecular weight band only. J, Representative Western blot for GluA2. Data are expressed as the mean \pm SEM net intensities of the bands of interest normalized to actin. GluA1, $n=10$ rats/treatment group; GluA2, $n=7$ rats/treatment group. ${ }^{*} p<0.05$ compared with placebo + saline; $\# p<0.05$ comparing bars under brackets.

NAc shell just before injection of naloxone $(0.0,0.1 \mathrm{mg} / \mathrm{kg}, \mathrm{SC})$. Rats were observed for $15 \mathrm{~min}$ and somatic withdrawal signs were scored. The sum total of all somatic withdrawal signs as well as wet dog shakes alone depended on an interaction between treatment and dependence (Fig. $3 A ; F_{(2,34)}=7.99, p<0.01$; Fig. $3 B$; $\left.F_{(2,34)}=11.98, p<0.01\right)$, whereas cage crossings depended on treatment (Fig. $3 C ; F_{(2,34)}=5.01, p<0.05$ ). In each case, naloxone increased somatic withdrawal signs significantly in morphine-dependent rats compared with placebo controls $(p<$ 0.01 ) and intra-NAc shell NBQX had no effect on naloxoneprecipitated somatic withdrawal signs.
Inhibition of NAc shell AMPARs attenuates naloxone-induced decreases in reward sensitivity in morphinedependent rats

To confirm that the ability of intra-NAc shell NBQX to block naloxone-induced conditioned place aversions is due to inhibition of morphine-withdrawalinduced negative-affective states rather than being a more general effect on associative learning and memory, ICSS was used to measure the effects of NBQX on brain stimulation reward. ICSS is an operant paradigm that-in trained rats-is sensitive to increases and decreases in reward independently of learning (Carlezon and Chartoff, 2007). First, a dose of naloxone that produces significant increases in ICSS thresholds in morphine-dependent rats was determined (indicative of a decrease in reward function attributed to precipitated morphine withdrawal). A one-way ANOVA showed that the effect of naloxone on ICSS thresholds was dose dependent (Fig. $4 A ; F_{(4,31)}=9.04, p<$ 0.01 ), with post hoc tests showing a significant increase in ICSS thresholds in the first $30 \mathrm{~min}$ after naloxone $(0.3 \mathrm{mg} / \mathrm{kg})$. Second, a dose-effect function for NBQX in ICSS was determined in nondependent rats. The effect of NBQX on ICSS thresholds was dose dependent (Fig. $4 B ; F_{(4,14)}=$ $5.12, p<0.01$ ), with post hoc tests showing a significant decrease in ICSS thresholds in the first $30 \mathrm{~min}$ after the highest dose of NBQX $(1.0 \mu \mathrm{g} / \mathrm{side})$. A separate cohort of morphine-dependent rats trained in ICSS was used to demonstrate that NBQX $(0.1 \mathrm{mg} / \mathrm{side})$ attenuated the thresholdincreasing effects of naloxone. A two-way, repeated-measures ANOVA showed that the effects of NBQX and naloxone depended on treatment (Fig. $4 C ; F_{(2,8)}=$ $11.52, p<0.05)$ and a simple main-effects test showed that naloxone $(0.3 \mathrm{mg} / \mathrm{kg})$ alone increased ICSS thresholds significantly relative to vehicle control [NBQX $(0.0)+$ naloxone $(0.0) ; p<0.05]$. When these time course data are collapsed across the first 30 min of drug treatments, a oneway ANOVA showed a significant effect (Fig. $4 D ; F_{(2,8)}=16.45, p<0.05$ ), with post hoc tests showing that NBQX decreased naloxone-induced elevations in thresholds significantly $(p<0.05)$. Neither NBQX nor naloxone had a significant effect on maximum rates of responding (Fig. $4 E ; F_{(2,8)}=1.52$, ns). Bilateral cannula placements for the rats used in Figure $4, B, D$, and $E$, are shown in Figure $4 F$.

\section{Morphine dependence is associated with increased surface expression of GluA1 AMPAR subunits that is reversed upon naloxone treatment}

To analyze the effects of morphine dependence and withdrawal on subcellular localization of AMPA GluA subunits 1 and 2, BS ${ }^{3}$ 
cross-linking of NAc tissue was performed. This technique, which relies on the ability of $\mathrm{BS}^{3}$ to covalently cross-link cell-surface-expressed proteins while leaving intracellular proteins unaffected, enables surface and intracellular receptor pools to be distinguished and measured. Whereas methods such as protein fractionation can show whether AMPAR subunits are associated with cell surface membranes (e.g., fraction P2), only surface cross-linking can show whether AMPAR subunits are physically on the cell surface. In addition, BS $^{3}$ cross-linking allows for the determination of surface to intracellular ratios of AMPAR subunits and their comparison with total subunit levels.

For surface/intracellular ratios of GluA1, a one-way ANOVA showed a significant effect of treatment (Fig. $5 A$; $\left.F_{(3,36)}=3.38, p<0.05\right)$, with Bonferroni post hoc test showing the morphine + saline group significantly higher than the placebo + saline group, whereas surface/ intracellular levels of morphine + naloxone were not significantly different from placebo + saline. Surface levels of GluA1 depended on treatment (Fig. $5 C ; F_{(3,36)}=$ 3.26, $p<0.05$ ), with morphine + saline significantly higher than morphine + naloxone. Neither total nor intracellular levels of GluA1 were significantly altered by treatment (Fig. 5B,D; $F_{(3,36)}=1.02$, ns; $F_{(3,36)}=0.40$, ns, respectively). Representative Western blot images of $\mathrm{BS}^{3}$ crosslinked tissue probed for GluA1 are shown in Figure $5 E$. Treatment had no effect on surface or intracellular expression levels of GluA2 in NAc tissue (Fig. 5F--I, with representative Western blot images of $\mathrm{BS}^{3}$ cross-linked tissue probed for GluA2 in Fig. 5J).

\section{Naloxone-precipitated morphine withdrawal decreases expression of GluA1 AMPAR subunits in NAc synaptosomal membranes}

To further analyze the effects of morphine dependence and withdrawal on subcellular localization of AMPA GluA subunits 1 and 2 , biochemical fractionation of NAc and $\mathrm{CPu}$ tissue was performed (see Fig. $6 \mathrm{~A}$ for anatomical location of tissue punches). To evaluate the effectiveness of the subcellular fractionation procedure, Western blots of protein samples from the isolated fractions were probed with antibodies specific to protein markers for subcellular compartments (Fig. 6B). The NMDA-receptor-anchoring protein PSD-95 is localized primarily in fraction P2 (crude synaptosomal membranes), which is consistent with its known intracellular distribution to the postsynaptic density (Ziff, 1997). Calnexin, a calciumbinding protein integral to the endoplasmic reticulum (ER) (Bergeron et al., 1994) and the TfR, a recycling endosome marker,

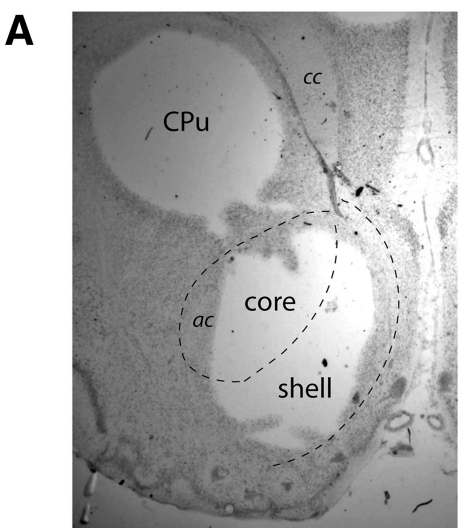

B
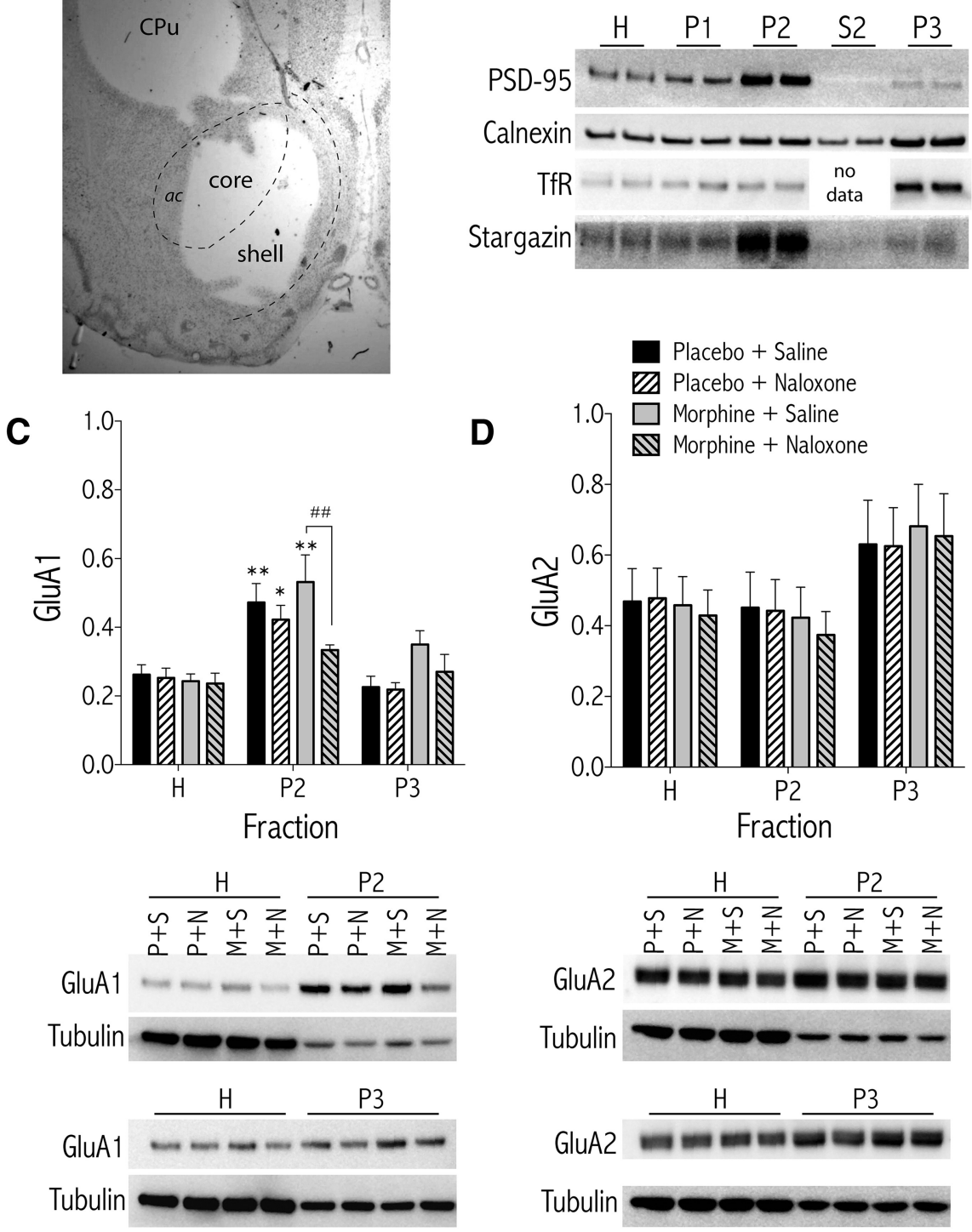

D
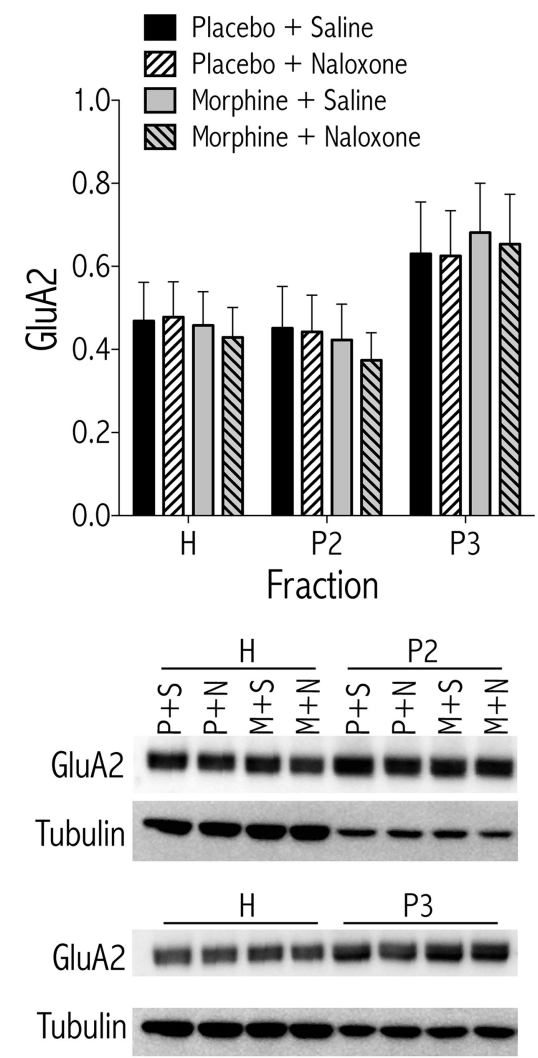

Figure 6. Biochemical fractionation of NAc tissue from morphine-dependent rats treated with naloxone shows a naloxoneinduced decrease in GluA1 AMPAR subunit in synaptosomal membranes (Fraction P2). $A$, Representative histology image showing a Nissl-stained coronal section at the level of the NAc, after tissue from the CPu and the NAc were removed. ac, Anterior commissure; cc, corpus callosum. $\boldsymbol{B}$, Characterization of subcellular compartments. Isolated biochemical fractions from NAc tissue were separated by denaturing gel electrophoreses and the blots were probed with antibodies against PSD-95, calnexin, TfR, and stargazin. PSD-95 and stargazin are highly concentrated in the synaptosomal membranes (P2), whereas TfR and calnexin are enriched in the light membrane fraction (P3). Densitometric quantification of AMPAR subunits GluA1 (C) or GluA2 (D) from NAC tissue of morphine-dependent or control rats treated with naloxone $(1.0 \mathrm{mg} / \mathrm{kg}, \mathrm{SC})$ or vehicle (saline), $n=10$ rats/treatment group. Data are expressed as the mean \pm SEM net intensities of GluA1 or GluA2 divided by tubulin for each sample to control for differences in protein loading. ${ }^{*} p<0.05,{ }^{* *} p<0.01$ compared with the total $(\mathrm{H})$ fraction for each treatment. \#\#p $<0.01$ comparing treatments under brackets. Representative blots for each protein are shown below the graphs. $\mathrm{H}$, Total homogenate; $\mathrm{P2}$, synaptosomal membranes; $\mathrm{P} 3$, light membranes (e.g., endoplasmic reticulum, recycling endosomes); $\mathrm{P}+\mathrm{S}$, placebo + saline; $\mathrm{P}+\mathrm{N}$, placebo + naloxone; $\mathrm{M}+\mathrm{S}$, morphine + saline; $\mathrm{M}+\mathrm{N}$, morphine + naloxone.

are enriched in fraction P3 (light membranes, including ER, Golgi, and recycling endosomes). Stargazin, a member of the transmembrane AMPAR regulatory protein (TARP) family, regulates AMPAR trafficking and channel kinetics (Tomita et al., 2003) and is enriched in fraction $\mathrm{P} 2$.

The subcellular localization of GluA1 in the NAc depended on an interaction between treatment and fraction (Fig. $6 C$, see representative Western blot images below graph; $F_{(6,72)}=2.26, p<$ $0.05)$, with post hoc analysis showing significantly less GluA1 in 
Table 1. Protein levels in fractionated samples from $\mathrm{CPu}$

\begin{tabular}{|c|c|c|c|c|c|c|c|c|c|}
\hline \multirow[b]{3}{*}{$\mathrm{CPu}$} & \multicolumn{9}{|l|}{ Protein } \\
\hline & \multicolumn{3}{|l|}{ GluA1 } & \multicolumn{3}{|l|}{ P-GluA1 } & \multicolumn{3}{|l|}{ GluA2 } \\
\hline & \multicolumn{9}{|l|}{ Fraction } \\
\hline Treatment & H & P2 & P3 & H & P2 & P3 & H & P2 & P3 \\
\hline PS & $0.116(0.028)$ & $0.630^{*}(0.209)$ & $0.158(0.030)$ & $0.026(0.004)$ & $0.117^{*}(0.023)$ & $0.033(0.005)$ & $0.677(0.080)$ & $0.669(0.188)$ & $0.908(0.128)$ \\
\hline PN & $0.100(0.012)$ & $0.597^{* *}(0.148)$ & $0.151(0.025)$ & $0.034(0.003)$ & $0.115^{*}(0.020)$ & $0.033(0.005)$ & $0.791(0.073)$ & $0.689(0.179)$ & $0.871(0.134)$ \\
\hline MS & $0.100(0.016)$ & $0.645^{* *}(0.197)$ & $0.186(0.064)$ & $0.027(0.002)$ & $0.164^{* *}(0.068)$ & $0.038(0.012)$ & $0.821(0.113)$ & $0.941(0.173)$ & $0.801(0.128)$ \\
\hline MN & $0.112(0.017)$ & $0.531^{*}(0.144)$ & $0.236(0.079)$ & $0.035(0.001)$ & $0.158^{*}(0.027)$ & $0.050(0.006)$ & $0.800(0.102)$ & $1.113(0.228)$ & $0.835(0.133)$ \\
\hline
\end{tabular}

Values are shown as net intensity of protein of interest/tubulin (SEM).

$\mathrm{PS}$, Placebo + saline; PN, placebo + naloxone; MS, morphine + saline; $M N$, morphine + naloxone.

${ }^{* *} p<0.01,{ }^{*} p<0.05$ compared with $\mathrm{H}$ fraction of the same treatment.

synaptosomal membranes (fraction P2) of morphine-dependent rats treated with naloxone compared with dependent rats treated with saline $(p<0.05)$. Furthermore, GluA1 levels in the P2 fraction from all treatment groups except for morphine + naloxone were significantly greater than GluAl levels in the $\mathrm{H}$ fraction of their corresponding treatments. Although NAc GluA1 levels appear elevated in the P3 fraction from morphine-dependent and morphine-withdrawn rats, there were no significant differences. There was no significant effect of treatment on total GluA1 levels (fraction H). Subcellular localization of NAc GluA2 subunits was unaffected by morphine dependence or naloxone-precipitated withdrawal (Fig. $6 D$, see representative Western blot images below graph; $F_{(3,36)}=0.040$, ns). In the $\mathrm{CPu}$, there was a significant effect of fraction (Table $1 ; F_{(2,38)}=35.19, p<0.001$ ), with Bonferroni post hoc tests showing that GluA1 levels in the CPu P2 fraction were significantly higher than GluA1 levels of corresponding treatments in the $\mathrm{H}$ fraction. However, there was no evidence of treatment-dependent GluA1 trafficking in tissue from the dorsal striatum (Table 1).

Because phosphorylation of GluA1 at the PKA-sensitive serine 845 (P-GluA1 Ser ${ }^{845}$ ) site is associated with subunit trafficking within subcellular compartments and with increased channel open probability (Song and Huganir, 2002; Esteban et al., 2003), we measured P-GluA1 Ser ${ }^{845}$ in fractionated NAc tissue punches from morphine-dependent and morphine-withdrawn rats and nondependent controls. The subcellular localization of P-GluA1 Ser ${ }^{845}$ in the NAc depended only on fraction (Fig. $7 A$, see representative Western blot images below graphs; $\left.F_{(2,72)}=47.12, p<0.001\right)$, with Bonferroni post hoc tests showing that P-GluA1 Ser ${ }^{845}$ levels in the NAc P2 fraction from all treatments except morphine + naloxone were significantly higher than P-GluA1 Ser ${ }^{845}$ levels of corresponding treatments in the $\mathrm{H}$ fraction. When the ratio of P-GluA1 Ser ${ }^{845}$ to GluA1 levels was analyzed in the NAc, the effects depended on treatment (Fig. $7 B, F_{(3,36)}=3.01, p<$ $0.05)$. Bonferroni post hoc tests show that P-GluA1 Ser ${ }^{845}$ /GluA1 levels in the $\mathrm{H}$ fraction from rats treated with morphine + naloxone were significantly higher than any other treatment in that fraction. Although P-GluA1 Ser ${ }^{845} / \mathrm{GluA} 1$ levels in the $\mathrm{P} 3$ fraction from rats treated with morphine + naloxone were elevated relative to other treatments, the effect was not significant ( $p=0.254$ vs. placebo + saline). In the $\mathrm{CPu}$, there was a significant effect of fraction (Table $1 ; F_{(2,24)}=$ $32.15, p<0.001$ ), with Bonferroni post hoc tests showing that P-GluA1 Ser ${ }^{845}$ levels in the CPu P2 fraction were significantly higher than GluA1 levels of corresponding treatments in the $\mathrm{H}$ fraction.

\section{Selective inhibition of $\mathrm{Ca}^{2+}$-permeable, GluA2-lacking, AMPA receptors in the NAc shell attenuates naloxone- induced decreases in reward sensitivity in morphine- dependent rats}

Chronic morphine-induced increases in surface GluA1 AMPAR subunit levels in the NAc raise the possibility that $\mathrm{Ca}^{2+}$ permeable GluA2-lacking AMPARs are necessary for morphinewithdrawal-induced negative-affective states. To test this hypothesis, we treated morphine-dependent rats with the selective $\mathrm{Ca}^{2+}$-permeable AMPAR blocker NASPM before naloxoneprecipitated withdrawal and measured effects on brain stimulation reward. First, a dose-effect function of intra-NAc NASPM on ICSS thresholds was determined in nondependent rats. One-way ANOVA showed no significant effect of any dose on ICSS thresholds (Fig. $8 A ; F_{(3,23)}=1.98, \mathrm{~ns}$ ). A separate cohort of rats trained in ICSS was used to demonstrate that NASPM $(5.0 \mu \mathrm{g} /$ side $)$ attenuated the threshold-increasing effects of naloxone in morphine-dependent rats. A two-way, repeatedmeasures ANOVA showed that the effects of NASPM and naloxone depended on treatment (Fig. $8 B ; F_{(2,8)}=13.68, p<$ $0.05)$ and simple main-effects tests showed that naloxone $(0.3$ $\mathrm{mg} / \mathrm{kg}$ ) increased ICSS thresholds significantly relative to vehicle control [NBQX (0.0) + naloxone (0.0)] regardless of NASPM pretreatment $(p<0.01)$. Furthermore, NASPM attenuated naloxone-induced increases in ICSS thresholds significantly $(p<$ 0.01 ). When these time course data are collapsed across the first 30 min of drug treatments, a one-way ANOVA showed a significant treatment effect (Fig. $8 C ; F_{(2,8)}=9.23, p<0.05$ ), with post hoc tests showing that NASPM $(0.0)$ + naloxone $(0.3)$ increased ICSS thresholds significantly relative to vehicle control [NASPM $(0.0)+$ naloxone $(0.0)](p<0.05)$, whereas ICSS thresholds were not significantly increased relative to vehicle control in rats pretreated with NASPM (5.0). Neither NASPM nor naloxone had a significant effect on maximum rates of responding (Fig. $8 D$; $F_{(2,8)}=4.64$, ns). Bilateral cannula placements for the rats used in Figure $8, B-D$, are shown in Figure $8 E$.

\section{Discussion}

In this study, we show that GluA1-mediated AMPAR glutamate transmission in the NAc shell is necessary for negative-affective, but not somatic, signs of morphine withdrawal in rats. Administration of the selective AMPAR antagonist NBQX directly into the NAc shell of morphine-dependent rats attenuated naloxoneinduced conditioned place aversions and naloxone-induced decreases in brain stimulation reward. We provide biochemical evidence that chronic morphine exposure increases cell surface expression of GluA1, but not GluA2, AMPAR subunits in the 

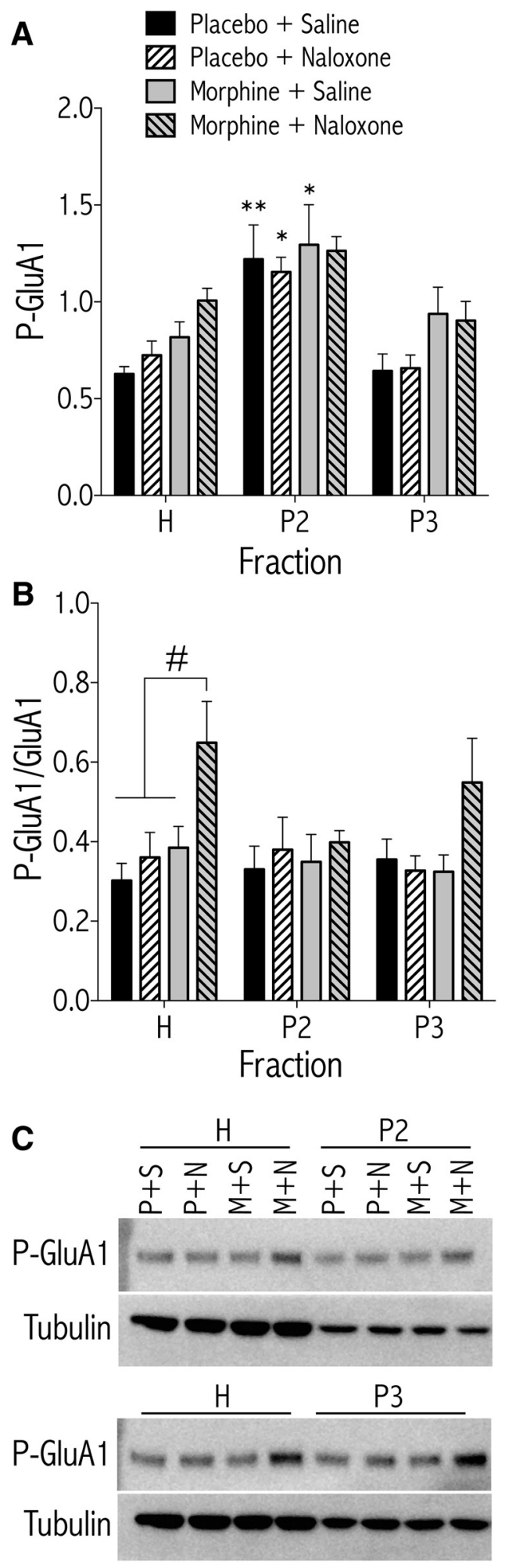

Figure 7. Biochemical fractionation of NAc tissue from morphine-dependent rats treated with naloxone shows elevated P-GluA1 $\left(\mathrm{Ser}^{845}\right) /$ GluA1 levels in the total homogenate $(\mathrm{H})$ fraction. Morphine-dependent and nondependent control rats were treated with naloxone $(1.0 \mathrm{mg} / \mathrm{kg}, \mathrm{SC})$ or vehicle $3 \mathrm{~d}$ after pellet implants and killed 30 min later ( $n=10$ rats/treatment group). Data are expressed as the mean \pm SEM net intensities of P-GluA1 alone, normalized to tubulin $(A)$ or as P-GluA1/GluA1 (see Fig. 6 C for total GluA1 expression) $(\boldsymbol{B}) .{ }^{*} p<0.05,{ }^{* *} p<0.01$ compared with the total $(\mathrm{H})$ fraction for each treatment $(\boldsymbol{A})$ or with groups indicated by bars $(\boldsymbol{B})$. $\boldsymbol{C}$, Representative Western blots.
NAc, which suggests synaptic insertion of GluA2-lacking AMPARs and a postsynaptic mechanism of synaptic potentiation. Consistent with this, administration of the GluA2-lacking AMPAR antagonist NASPM to morphine-dependent rats attenuated naloxone-induced decreases in brain stimulation reward. AMPAR blockade had no effect on the expression of somatic withdrawal signs, suggesting that AMPA transmission in the NAc shell modulates circuits involved in affective and motivational components of withdrawal selectively. Our results are broadly consistent with and extend a recent study in mice showing that chronic morphine-induced potentiation of AMPAR-mediated transmission in the NAc is necessary for morphine withdrawal signs (Zhu et al., 2016). Together with our finding that intra-NAc microinjection of AMPA caused place aversions in nondependent rats, these data are consistent with an expanding literature demonstrating that NAc neurons are activated in response to aversive, and inhibited in response to rewarding, stimuli (Peoples and West, 1996; Carelli, 2002; Roitman et al., 2005).

\section{Role of NAc AMPARs in affective withdrawal signs}

The sources of increased glutamate in the NAc shell during morphine withdrawal are not known, but may be similar to what has been shown for excitatory inputs to the ventral tegmental area (Manzoni and Williams, 1999). This includes relief of tonic inhibitory effects of morphine on glutamatergic afferents from prefrontal cortex, basolateral amygdala, hippocampus, or-as a recent study showed-paraventricular nucleus of the thalamus (Zahm and Brog, 1992; O'Donnell and Grace, 1995; Zhu et al., 2016). It is also possible that morphine withdrawal affects levels of nonsynaptic glutamate through modulation of glutamate uptake, which in turn shapes excitatory synaptic transmission (Kalivas, 2009). Regardless, the effect of AMPAR blockade in this study was specific to the NAc shell because, when NBQX was microinjected dorsal to the NAc shell, place aversions were not blocked. Other studies have demonstrated a rostral-caudal gradient in the effects of AMPAR activation on hedonic state and motivated behavior (Faure et al., 2010). In contrast, the effects of NBQX on naloxone-induced place aversions were similar regardless of cannulae placement along the rostral-caudal NAc axis.

Excitatory synaptic transmission is critical for learning and memory (Kessels and Malinow, 2009). It is possible that NBQX impaired the ability of rats to form place associations rather than blocking withdrawal-induced negative-affective states. For example, GluA1 subunits in the central nucleus of the amygdala have been shown to facilitate associative learning of opiate reward (Cai et al., 2013), and increased trafficking of GluA1-containing AMPARs to synaptic zones in the amygdala is necessary for auditory fear conditioning (Rumpel et al., 2005). We show that intra-NAc shell NBQX counteracted naloxone-induced increases in ICSS thresholds, which can be interpreted to mean that AMPAR blockade attenuates withdrawal-associated anhedonia. NBQX on its own did not alter ICSS thresholds, suggesting that the ability of NBQX to decrease withdrawal-induced aversive states was not because NBQX itself was rewarding. Neither NBQX nor naloxone had any effect on maximum rates of lever pressing, suggesting that the effects on stimulation thresholds were not due to alterations in motor capacity. Together, these findings support the idea that AMPAR transmission in the NAc shell is necessary for regulation of hedonic state (Todtenkopf et al., 2006).

NBQX is a selective AMPAR antagonist with no observable activity at NMDA receptors in ex vivo slice preparations (Goldstein and Litwin, 1993). In contrast to a previous study (Boldry et 
A

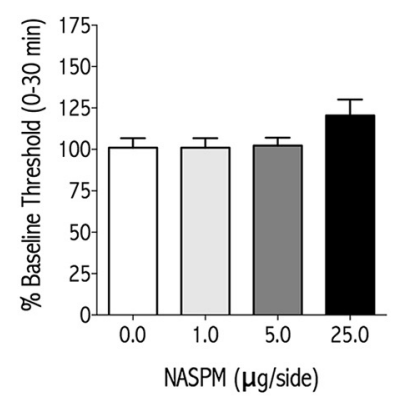

C

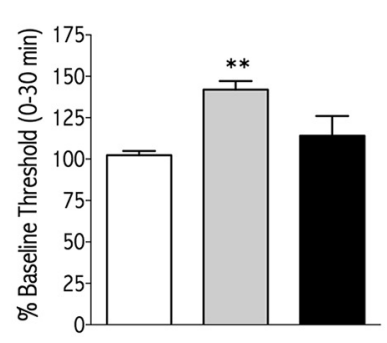

B

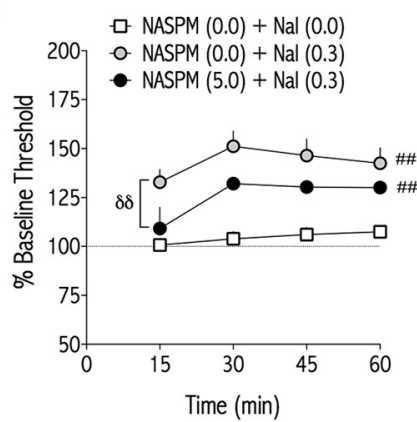

D

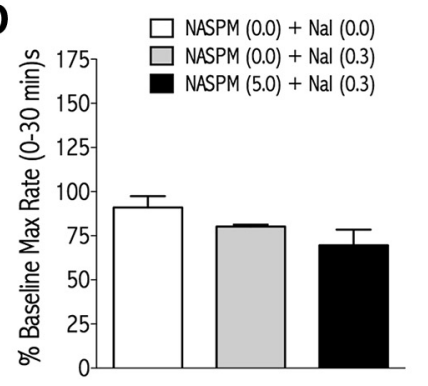

E

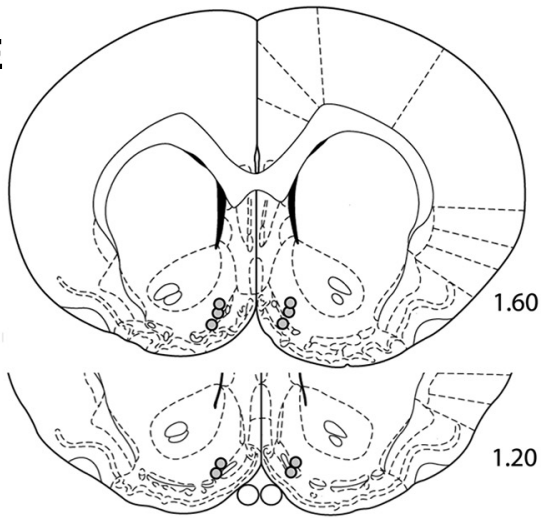

Figure 8. Administration of NASPM, a selective antagonist of $\mathrm{Ca}^{2+}$-permeable AMPARs, into the NAc shell attenuates naloxone-induced decreases in brain stimulation reward in morphinedependent rats. $A$, Nondependent rats with bilateral cannulae in the NAc shell and stimulating electrodes in the medial forebrain bundle were administered NASPM $(0.0,1.0,5.0,25.0 \mu \mathrm{g} / \mathrm{side}, \mathrm{NAc}$ shell; $n=6$ ) and effects on ICSS thresholds were measured. $\boldsymbol{B}$, Rats with bilateral cannulae in the NAc shell and stimulating electrodes were implanted with morphine pellets $(n=5)$ and, beginning 3 d later, the effects of NASPM $(0.0,5.0 \mu \mathrm{g} / \mathrm{side})$ and naloxone $(0.0,0.3 \mathrm{mg} / \mathrm{kg}, \mathrm{SC})$ on ICSS thresholds were measured for $60 \mathrm{~min}$. C, Average change in percentage baseline thresholds was calculated for the first 30 min after drug treatment. $D$, Average change in percentage maximum rates of responding was calculated for the first 30 min after drug treatment. Data are expressed as mean \pm SEM percentage change from daily, pre-drug baseline thresholds. \#\# $<0.01$ main effect of treatment compared with NASPM $(0.0)+$ naloxone $(0.0) ; \delta \delta p<0.01$ main effect of treatment comparing groups in brackets. ${ }^{* *} p<0.01$ compared with NASPM $(0.0)+$ naloxone (0.0). $\boldsymbol{E}$, Microinjection placements from NASPM-treated rats included in $\boldsymbol{B}-\boldsymbol{D}$.

al., 1993), we found that intra-NAc shell NBQX produced a dosedependent increase in locomotor activity, with the highest dose also decreasing ICSS thresholds. These effects are similar to those observed with NMDA receptor antagonists (Carlezon and Wise, 1993; Chartoff et al., 2005). Therefore, high doses of NBQX might reduce neuronal depolarization to the point that NMDA receptors are effectively blocked. To avoid this possible confound, NBQX was used at a dose that completely blocked AMPAinduced locomotor activity but had no effects on its own.

One caveat to the ICSS experiments is that the dose of naloxone necessary to increase stimulation thresholds significantly also produces somatic withdrawal signs (Chartoff et al., 2006b) and is higher than that needed to produce place aversions in morphinedependent rats. Because ICSS activates dopamine neurons indirectly (Bielajew et al., 2003), it is possible that greater muopioid-receptor blockade is necessary to counteract stimulationinduced dopamine release (Owesson-White et al., 2008). Regardless, NBQX and NASPM attenuated withdrawal-induced decreases in reward function in ICSS, which measures the effect of a manipulation on reward in real time and is not dependent on learning (Carlezon and Chartoff, 2007).

\section{Role of NAc AMPARs in somatic withdrawal signs}

Dopamine transmission in the NAc has been implicated in the somatic signs of morphine withdrawal (Harris and Aston-Jones, 1994; but see Chartoff et al., 2009) and systemic administration of an AMPAR antagonist attenuates somatic morphine withdrawal signs (Rasmussen et al., 1996). However, intra-NAc shell NBQX failed to attenuate any somatic withdrawal signs in morphinedependent rats. This is consistent with prior work showing that activation of dopamine D1 receptors in the VTA blocks naloxone-induced place aversions, but not somatic withdrawal signs (Chartoff et al., 2009), and suggests that the neurobiological mechanisms underlying somatic and affective signs of withdrawal can be dissociated.

\section{Effects of morphine dependence on AMPAR subunit plasticity}

Drugs of abuse induce plasticity, including postsynaptic modulation of AMPAR trafficking. However, the specifics of druginduced alterations in AMPAR function are dependent on drug class and administration regimen (Glass et al., 2008; Wolf and Tseng, 2012; Hearing et al., 2016). The dependence-inducing regimen of implanted morphine pellets used in the current study was associated with an increase in the ratio of surface to intracellular GluA1 expression in the NAc, a finding due primarily to increased GluA1 surface expression. Our findings are consistent with a recent study in which an escalating dose regimen of morphine known to produce dependence strengthens glutamatergic inputs from the paraventricular nucleus of the thalamus to the NAc by postsynaptic insertion of GluA2-lacking AMPARs (Zhu et al., 2016). AMPARs that lack GluA2 subunits are unique in that they are $\mathrm{Ca}^{2+}$-permeable and exhibit larger single channel conductance and faster kinetics than GluA2-containing AMPARs (Liu and Cull-Candy, 2000), thus enabling greater depolarization and activation of $\mathrm{Ca}^{2+}$-mediated signal transduction cascades. The exact subunit composition of morphine-induced, surface expressed GluA2-lacking AMPARs is not known, but likely includes GluA1 homomers and GluA1-GluA3 heteromers (Reimers et al., 2011). 
Naloxone-precipitated withdrawal reversed morphine-induced increases in GluAl surface expression and decreased the amount of GluA1 localized to synaptosomal membrane fractions. Given that morphine withdrawal increases extracellular glutamate in the NAc (Sepúlveda et al., 1998), it is possible that removal of GluA1 from synaptosomal membranes is a form of synaptic scaling (Turrigiano, 2008; Sun and Wolf, 2009), although the functional consequences of this for behavior are not known. After excessive or prolonged stimulation, AMPARs are endocytosed into endosomal compartments and then sorted into either recycling endosomes or lysosomes, where they are targeted for degradation (Ehlers, 2000). Recycling, but not degradative, endosomes express TfRs (Ehlers, 2000) and the P3 fraction is enriched for TfRs. We observed a trend for an increase in P3 GluA1 expression in morphine-dependent and morphinewithdrawn NAc tissue, which could account for the withdrawalinduced decrease in synaptosomal GluA1. It is also possible that GluA1 subunits are trafficked out of synaptosomal membranes to TfR-lacking lysosomes that are not segregated with our fractionation conditions. Previous work has shown that internalized AMPARs are degraded over the course of hours (Ehlers, 2000), suggesting that degradation of GluAl occurs slowly relative to trafficking and would not have been detected $30 \mathrm{~min}$ after naloxone. Neither morphine dependence nor withdrawal changed the subcellular localization of GluA2 subunits, which may be related to the finding that synaptic expression of GluAl is activity dependent, whereas GluA2 is recycled constitutively (Contractor and Heinemann, 2002).

Morphine withdrawal unmasks increased cAMP-dependent protein kinase (PKA) signaling (Nestler and Aghajanian, 1997; Chartoff et al., 2006b). NAc GluA1 subunits in the total cell homogenate of naloxone-treated, morphine-dependent rats had a significantly higher level of PKA-mediated phosphorylation at $\mathrm{Ser}^{845}$ compared with GluA1 subunits from control and morphine-dependent rats. Prior work has shown that phosphorylation is necessary- but not sufficient—for trafficking of GluA1 subunits to synapses (Esteban et al., 2003). However, in the current study, the bulk of increased P-GluA1 was localized to the intracellular light membrane fraction (P3). These findings suggest that morphine withdrawal triggers simultaneous and potentially competing events: PKA-mediated GluA1 phosphorylation and internalization of GluA1 subunits (many of which are now phosphorylated) in response to increased glutamate.

\section{Conclusions}

Evidence suggests that GluA1 in the NAc contributes to aversive states (Kelz et al., 1999; Todtenkopf et al., 2006) and that AMPAR trafficking is instrumental in opioid addiction (Nelson et al., 2016; Zhu et al., 2016). The finding that increased AMPAR transmission in the NAc shell contributes to affective, but not somatic, signs of morphine withdrawal adds to prior work showing that reinstatement of cocaine and heroin seeking is dependent upon increased glutamate release into the NAc (McFarland and Kalivas, 2001; LaLumiere and Kalivas, 2008; Hearing et al., 2016) by raising the possibility that activation of AMPARs in the NAc can produce aversive states that motivate drug seeking. Regardless, these findings suggest that manipulations that decrease NAc AMPAR transmission might be a useful approach for the treatment of negative-affective states that contribute to the maintenance of opiate addiction in humans.

\section{References}

Baker TB, Piper ME, McCarthy DE, Majeskie MR, Fiore MC (2004) Addiction motivation reformulated: an affective processing model of negative reinforcement. Psychol Rev 111:33-51. CrossRef Medline

Bari AA, Pierce RC (2005) D1-like and D2 dopamine receptor antagonists administered into the shell subregion of the rat nucleus accumbens decrease cocaine, but not food, reinforcement. Neuroscience 135:959-968. CrossRef Medline

Bergeron JJ, Brenner MB, Thomas DY, Williams DB (1994) Calnexin: a membrane-bound chaperone of the endoplasmic reticulum. Trends Biochem Sci 19:124-128. CrossRef Medline

Bielajew C, Konkle AT, Kentner AC, Baker SL, Stewart A, Hutchins AA, Santa-Maria Barbagallo L, Fouriezos G (2003) Strain and gender specific effects in the forced swim test: effects of previous stress exposure. Stress 6:269-280. CrossRef Medline

Boldry RC, Kelland MD, Engber TM, Chase TN (1993) NBQX inhibits AMPA-induced locomotion after injection into the nucleus accumbens. Brain Res 600:331-334. CrossRef Medline

Boudreau AC, Milovanovic M, Conrad KL, Nelson C, Ferrario CR, Wolf ME (2012) A protein cross-linking assay for measuring cell surface expression of glutamate receptor subunits in the rodent brain after in vivo treatments. Curr Protoc Neurosci Chapter 5:Unit 5.30.1-19. CrossRef Medline

Cai YQ, Wang W, Hou YY, Zhang Z, Xie J, Pan ZZ (2013) Central amygdala GluAl facilitates associative learning of opioid reward. J Neurosci 33: 1577-1588. CrossRef Medline

Carelli RM (2002) The nucleus accumbens and reward: neurophysiological investigations in behaving animals. Behav Cogn Neurosci Rev 1:281-296. CrossRef Medline

Carlezon WA Jr, Chartoff EH (2007) Intracranial self-stimulation (ICSS) in rodents to study the neurobiology of motivation. Nat Protoc 2:29872995. Medline

Carlezon WA Jr, Nestler EJ (2002) Elevated levels of GluR1 in the midbrain: a trigger for sensitization to drugs of abuse? Trends Neurosci 25:610-615. CrossRef Medline

Carlezon WA Jr, Thomas MJ (2009) Biological substrates of reward and aversion: a nucleus accumbens activity hypothesis. Neuropharmacology 56:122-132. CrossRef Medline

Carlezon WA Jr, Wise RA (1993) Phencyclidine-induced potentiation of brain stimulation reward: acute effects are not altered by repeated administration. Psychopharmacologia (Berl) 111:402-408. Medline

Carlezon WA Jr, Wise RA (1996) Microinjections of phencyclidine (PCP) and related drugs into nucleus accumbens shell potentiate medial forebrain bundle brain stimulation reward. Psychopharmacologia 128:413-420. Medline

Chartoff EH, Heusner CL, Palmiter RD (2005) Dopamine is not required for the hyperlocomotor response to NMDA receptor antagonists. Neuropsychopharmacology 30:1324-1333. Medline

Chartoff EH, Pliakas AM, Carlezon WA Jr (2006a) Microinjection of the L-type calcium channel antagonist diltiazem into the ventral nucleus accumbens shell facilitates cocaine-induced conditioned place preferences. Biol Psychiatry 59:1236-1239. CrossRef Medline

Chartoff EH, Mague SD, Barhight MF, Smith AM, Carlezon WA Jr (2006b) Behavioral and molecular effects of dopamine D1 receptor stimulation during naloxone-precipitated morphine withdrawal. J Neurosci 26: 6450-6457. CrossRef Medline

Chartoff EH, Potter D, Damez-Werno D, Cohen BM, Carlezon WA Jr (2008) Exposure to the selective kappa-opioid receptor agonist salvinorin A modulates the behavioral and molecular effects of cocaine in rats. Neuropsychopharmacology 33:2676-2687. CrossRef Medline

Chartoff EH, Barhight MF, Mague SD, Sawyer AM, Carlezon WA Jr (2009) Anatomically dissociable effects of dopamine D1 receptor agonists on reward and relief of withdrawal in morphine-dependent rats. Psychopharmacology 204:227-239. CrossRef Medline

Contractor A, Heinemann SF (2002) Glutamate receptor trafficking in synaptic plasticity. Sci STKE 2002:re14. Medline

Cottone P, Sabino V, Roberto M, Bajo M, Pockros L, Frihauf JB, Fekete EM, Steardo L, Rice KC, Grigoriadis DE, Conti B, Koob GF, Zorrilla EP (2009) CRF system recruitment mediates dark side of compulsive eating. Proc Natl Acad Sci U S A 106:20016-20020. CrossRef Medline

Dunah AW, Standaert DG (2001) Dopamine D1 receptor-dependent traf- 
ficking of striatal NMDA glutamate receptors to the postsynaptic membrane. J Neurosci 21:5546-5558. Medline

Ebner SR, Roitman MF, Potter DN, Rachlin AB, Chartoff EH (2010) Depressive-like effects of the kappa opioid receptor agonist salvinorin A are associated with decreased phasic dopamine release in the nucleus accumbens. Psychopharmacology 210:241-252. CrossRef Medline

Ehlers MD (2000) Reinsertion or degradation of AMPA receptors determined by activity-dependent endocytic sorting. Neuron 28:511-525. CrossRef Medline

Esteban JA, Shi SH, Wilson C, Nuriya M, Huganir RL, Malinow R (2003) PKA phosphorylation of AMPA receptor subunits controls synaptic trafficking underlying plasticity. Nat Neurosci 6:136-143. CrossRef Medline

Faure A, Richard JM, Berridge KC (2010) Desire and dread from the nucleus accumbens: cortical glutamate and subcortical GABA differentially generate motivation and hedonic impact in the rat. PLoS One 5:e11223. CrossRef Medline

Glass MJ, Lane DA, Colago EE, Chan J, Schlussman SD, Zhou Y, Kreek MJ, Pickel VM (2008) Chronic administration of morphine is associated with a decrease in surface AMPA GluR1 receptor subunit in dopamine D1 receptor expressing neurons in the shell and non-D1 receptor expressing neurons in the core of the rat nucleus accumbens. Exp Neurol 210:750761. CrossRef Medline

Gold LH, Stinus L, Inturrisi CE, Koob GF (1994) Prolonged tolerance, dependence and abstinence following subcutaneous morphine pellet implantation in the rat. Eur J Pharmacol 253:45-51. CrossRef Medline

Goldstein JM, Litwin LC (1993) NBQX is a selective non-NMDA receptor antagonist in rat hippocampal slice. Mol Chem Neuropathol 18:145-152. CrossRef Medline

Gracy KN, Dankiewicz LA, Koob GF (2001) Opiate withdrawal-induced fos immunoreactivity in the rat extended amygdala parallels the development of conditioned place aversion. Neuropsychopharmacology 24:152-160. CrossRef Medline

Hallett PJ, Collins TL, Standaert DG, Dunah AW (2008) Biochemical fractionation of brain tissue for studies of receptor distribution and trafficking. Curr Protoc Neurosci Chapter 1:Unit 1.16. CrossRef Medline

Harris GC, Aston-Jones G (1994) Involvement of D2 dopamine receptors in the nucleus accumbens in the opiate withdrawal syndrome. Nature 371 : 155-157. CrossRef Medline

Hasin D, Liu X, Nunes E, McCloud S, Samet S, Endicott J (2002) Effects of major depression on remission and relapse of substance dependence. Arch Gen Psychiatry 59:375-380. CrossRef Medline

Hearing MC, Jedynak J, Ebner SR, Ingebretson A, Asp AJ, Fischer RA, Schmidt C, Larson EB, Thomas MJ (2016) Reversal of morphineinduced cell-type-specific synaptic plasticity in the nucleus accumbens shell blocks reinstatement. Proc Natl Acad Sci U S A 113:757-762. CrossRef Medline

Hong M, Milne B, Jhamandas K (1993) Evidence for the involvement of excitatory amino acid pathways in the development of precipitated withdrawal from acute and chronic morphine: an in vivo voltammetric study in the rat locus coeruleus. Brain Res 623:131-141. CrossRef Medline

Kalivas PW (2009) The glutamate homeostasis hypothesis of addiction. Nat Rev Neurosci 10:561-572. CrossRef Medline

Kelz MB, Chen J, Carlezon WA Jr, Whisler K, Gilden L, Beckmann AM, Steffen C, Zhang YJ, Marotti L, Self DW, Tkatch T, Baranauskas G, Surmeier DJ, Neve RL, Duman RS, Picciotto MR, Nestler EJ (1999) Expression of the transcription factor deltaFosB in the brain controls sensitivity to cocaine. Nature 401:272-276. CrossRef Medline

Kessels HW, Malinow R (2009) Synaptic AMPA receptor plasticity and behavior. Neuron 61:340-350. CrossRef Medline

Koob GF, Le Moal M (2001) Drug addiction, dysregulation of reward, and allostasis. Neuropsychopharmacology 24:97-129. CrossRef Medline

Koob GF, Stinus L, Le Moal M, Bloom FE (1989) Opponent process theory of motivation: neurobiological evidence from studies of opiate dependence. Neurosci Biobehav Rev 13:135-140. CrossRef Medline

Koob GF, Maldonado R, Stinus L (1992) Neural substrates of opiate withdrawal. Trends Neurosci 15:186-191. CrossRef Medline

LaLumiere RT, Kalivas PW (2008) Glutamate release in the nucleus accumbens core is necessary for heroin seeking. J Neurosci 28:3170-3177. CrossRef Medline

Liu SQ, Cull-Candy SG (2000) Synaptic activity at calcium-permeable AMPA receptors induces a switch in receptor subtype. Nature 405:454458. CrossRef Medline
Manzoni OJ, Williams JT (1999) Presynaptic regulation of glutamate release in the ventral tegmental area during morphine withdrawal. J Neurosci 19:6629-6636. Medline

McFarland K, Kalivas PW (2001) The circuitry mediating cocaine-induced reinstatement of drug-seeking behavior. J Neurosci 21:8655-8663. Medline

Nakagawa T, Ozawa T, Shige K, Yamamoto R, Minami M, Satoh M (2001) Inhibition of morphine tolerance and dependence by MS-153, a glutamate transporter activator. Eur J Pharmacol 419:39-45. CrossRef Medline

Nelson EC, Agrawal A, Heath AC, Bogdan R, Sherva R, Zhang B, Al-Hasani R, Bruchas MR, Chou YL, Demers CH, Carey CE, Conley ED, Fakira AK, Farrer LA, Goate A, Gordon S, Henders AK, Hesselbrock V, Kapoor M, Lynskey MT, et al. (2016) Evidence of CNIH3 involvement in opioid dependence. Mol Psychiatry 21:608-614. CrossRef Medline

Nestler EJ (1996) Under siege: the brain on opiates. Neuron 16:897-900. CrossRef Medline

Nestler EJ, Aghajanian GK (1997) Molecular and cellular basis of addiction. Science 278:58-63. CrossRef Medline

O’Donnell P, Grace AA (1995) Synaptic interactions among excitatory afferents to nucleus accumbens neurons: hippocampal gating of prefrontal cortical input. J Neurosci 15:3622-3639. Medline

Olds ME (1982) Reinforcing effects of morphine in the nucleus accumbens. Brain Res 237:429-440. CrossRef Medline

Owesson-White CA, Cheer JF, Beyene M, Carelli RM, Wightman RM (2008) Dynamic changes in accumbens dopamine correlate with learning during intracranial self-stimulation. Proc Natl Acad Sci U S A 105:11957-11962. CrossRef Medline

Paxinos G (1995) The rat nervous system, Ed 2. San Diego: Academic.

Peoples LL, West MO (1996) Phasic firing of single neurons in the rat nucleus accumbens correlated with the timing of intravenous cocaine selfadministration. J Neurosci 16:3459-3473. Medline

Rasmussen K, Kendrick WT, Kogan JH, Aghajanian GK (1996) A selective AMPA antagonist, LY293558, suppresses morphine withdrawal-induced activation of locus coeruleus neurons and behavioral signs of morphine withdrawal. Neuropsychopharmacology 15:497-505. CrossRef Medline

Reimers JM, Milovanovic M, Wolf ME (2011) Quantitative analysis of AMPA receptor subunit composition in addiction-related brain regions. Brain Res 1367:223-233. CrossRef Medline

Roitman MF, Wheeler RA, Carelli RM (2005) Nucleus Accumbens neurons are innately tuned for rewarding and aversive taste stimuli, encode their predictors, and are linked to motor output. Neuron 45:587-597. CrossRef Medline

Rumpel S, LeDoux J, Zador A, Malinow R (2005) Postsynaptic receptor trafficking underlying a form of associative learning. Science 308:83-88. CrossRef Medline

Sekiya Y, Nakagawa T, Ozawa T, Minami M, Satoh M (2004) Facilitation of morphine withdrawal symptoms and morphine-induced conditioned place preference by a glutamate transporter inhibitor DL-threo-betabenzyloxyaspartate in rats. Eur J Pharmacol 485:201-210. CrossRef Medline

Sepúlveda J, Oliva P, Contreras E (2004) Neurochemical changes of the extracellular concentrations of glutamate and aspartate in the nucleus accumbens of rats after chronic administration of morphine. Eur J Pharmacol 483:249-258. CrossRef Medline

Sepúlveda MJ, Hernandez L, Rada P, Tucci S, Contreras E (1998) Effect of precipitated withdrawal on extracellular glutamate and aspartate in the nucleus accumbens of chronically morphine-treated rats: an in vivo microdialysis study. Pharmacol Biochem Behav 60:255-262. CrossRef Medline

Song I, Huganir RL (2002) Regulation of AMPA receptors during synaptic plasticity. Trends Neurosci 25:578-588. CrossRef Medline

Sun X, Wolf ME (2009) Nucleus accumbens neurons exhibit synaptic scaling that is occluded by repeated dopamine pre-exposure. Eur J Neurosci 30:539-550. CrossRef Medline

Svingos AL, Moriwaki A, Wang JB, Uhl GR, Pickel VM (1997) mu-Opioid receptors are localized to extrasynaptic plasma membranes of GABAergic neurons and their targets in the rat nucleus accumbens. J Neurosci 17: 2585-2594. Medline

Todtenkopf MS, Stellar JR (2000) Assessment of tyrosine hydroxylase immunoreactive innervation in five subregions of the nucleus accumbens 
shell in rats treated with repeated cocaine. Synapse 38:261-270. CrossRef Medline

Todtenkopf MS, Marcus JF, Portoghese PS, Carlezon WA Jr (2004) Effects of kappa-opioid receptor ligands on intracranial self-stimulation in rats. Psychopharmacology 172:463-470. CrossRef Medline

Todtenkopf MS, Parsegian A, Naydenov A, Neve RL, Konradi C, Carlezon WA Jr (2006) Brain reward regulated by AMPA receptor subunits in nucleus accumbens shell. J Neurosci 26:11665-11669. CrossRef Medline

Tomasiewicz HC, Todtenkopf MS, Chartoff EH, Cohen BM, Carlezon WA Jr (2008) The kappa-opioid agonist U69,593 blocks cocaine-induced enhancement of brain stimulation reward. Biol Psychiatry 64:982-988. CrossRef Medline

Tomita S, Chen L, Kawasaki Y, Petralia RS, Wenthold RJ, Nicoll RA, Bredt DS (2003) Functional studies and distribution define a family of transmembrane AMPA receptor regulatory proteins. J Cell Biol 161:805-816. CrossRef Medline

Turrigiano GG (2008) The self-tuning neuron: synaptic scaling of excitatory synapses. Cell 135:422-435. CrossRef Medline

Vekovischeva OY, Zamanillo D, Echenko O, Seppälä T, Uusi-Oukari M, Honkanen A, Seeburg PH, Sprengel R, Korpi ER (2001) Morphineinduced dependence and sensitization are altered in mice deficient in
AMPA-type glutamate receptor-A subunits. J Neurosci 21:4451-4459. Medline

Wikler A (1948) Recent progress in research on the neurophysiologic basis of morphine addiction. Am J Psychiatry 105:329-338. CrossRef Medline

Wise RA (1989) Opiate reward: sites and substrates. Neurosci Biobehav Rev 13:129-133. CrossRef Medline

Wise RA, Hoffman DC (1992) Localization of drug reward mechanisms by intracranial injections. Synapse 10:247-263. CrossRef Medline

Wolf ME, Tseng KY (2012) Calcium-permeable AMPA receptors in the VTA and nucleus accumbens after cocaine exposure: when, how, and why? Front Mol Neurosci 5:72. CrossRef Medline

Wolf ME, Sun X, Mangiavacchi S, Chao SZ (2004) Psychomotor stimulants and neuronal plasticity. Neuropharmacology 47:61-79. CrossRef Medline

Zahm DS, Brog JS (1992) On the significance of subterritories in the "accumbens" part of the rat ventral striatum. Neuroscience 50:751-767. CrossRef Medline

Zhu Y, Wienecke CF, Nachtrab G, Chen X (2016) A thalamic input to the nucleus accumbens mediates opiate dependence. Nature 530:219-222. CrossRef Medline

Ziff EB (1997) Enlightening the postsynaptic density. Neuron 19:11631174. CrossRef Medline 